KENT NEWMAN

\title{
DOCUMENTARY REALITY TELEVISION'S PRIVACY PROBLEM
}

\author{
A dissertation submitted to the Victoria University of Wellington in fulfilment of the \\ requirements for the degree of Masters of Law.
}

LAWS 592: DISSERTATION

FACULTY OF LAW

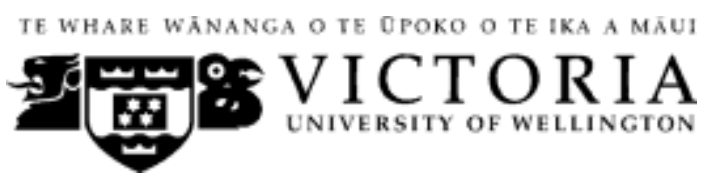

2020 


\section{Table of Contents}

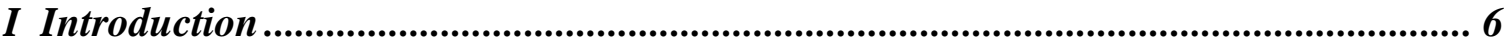

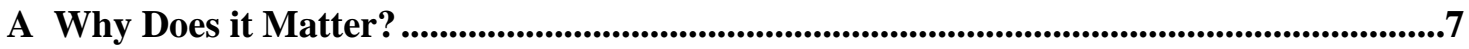

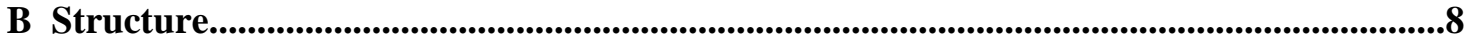

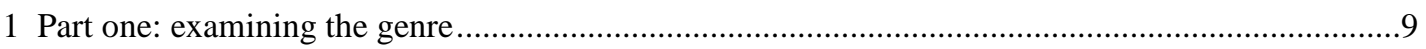

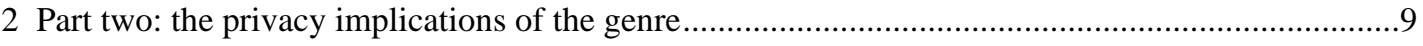

II What is Documentary Reality Television? ........................................................... 12

A The Origins of Documentary Reality Television ....................................................................12

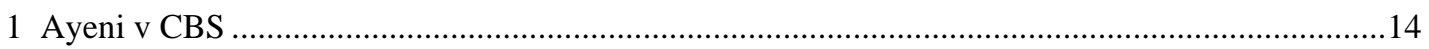

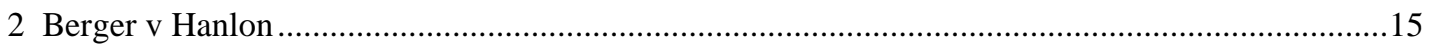

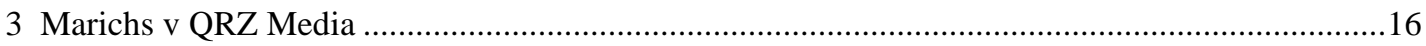

B Documentary Reality Television Arrives in New Zealand.............................................17

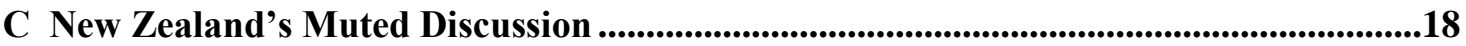

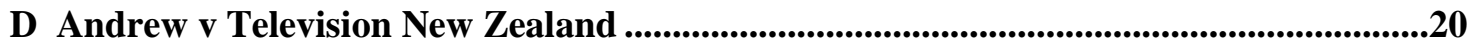

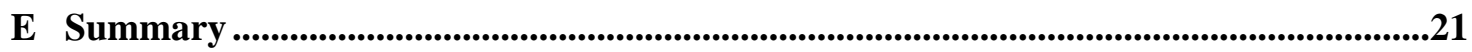

III The Parties and Relationships .............................................................................. 22

A The Relationship of the Production Company and the Agency .....................................22

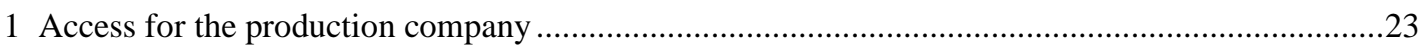

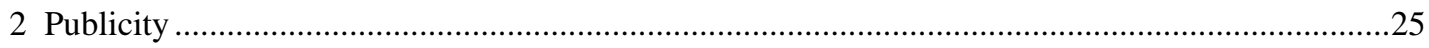

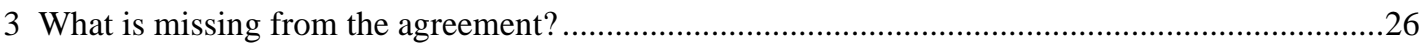

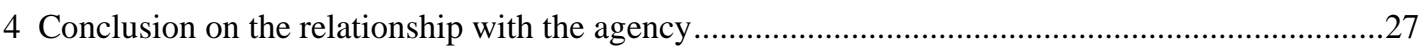

B The Relationship with Involuntary Participants .........................................................................27

C The Curious Situation of the Agencies' Employees.................................................................32

D Conclusion about the Parties and Their Relationships......................................................32

IV Could Authorising Agencies Be Liable for the Breach of Privacy? ......................... 34

A What is Required to be Joined to a Claim ...................................................................................34

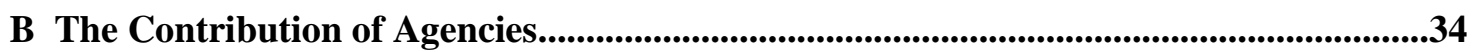

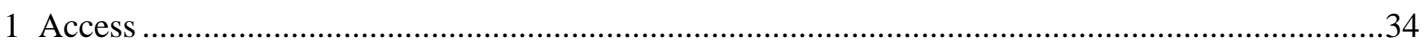

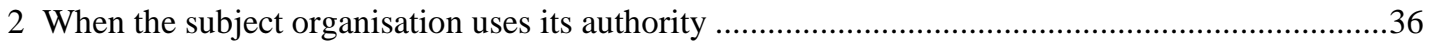

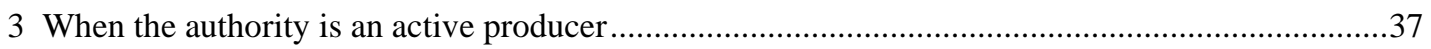

C Conclusion on Litigation Risk ...............................................................................................................38

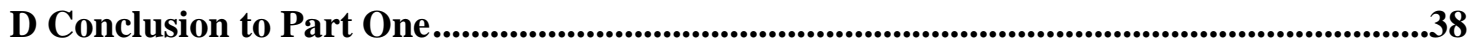

V A Framework for Breach of Privacy ...................................................................... 40 


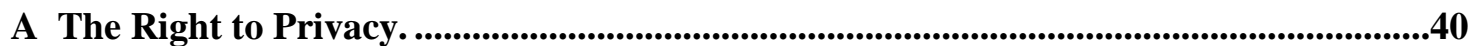

B The Instrumental Value of the Right to Privacy .....................................................................41

C Privacy Plays a Central Role in Dignity, Autonomy and Wellbeing. ................................43

D The Framework for Breach of Privacy by Publication......................................................44

E The First Element is the Reasonable Expectation of Privacy ...........................................44

F The Second Element is Highly Offensive Publication .....................................................45

G The Third Element is the Absence of a Defence ..........................................................46

H Conclusion on the Framework for Breach of Privacy .........................................................47

VI The Genre Broadcasts Private Material ................................................................ 48

A What is Meant by "a Reasonable Expectation of Privacy"? ..............................................48

B The New Access Focuses on Traditionally Protected Spatial Areas .................................50

C Access to Spatial Areas Traditionally Protected .......................................................................50

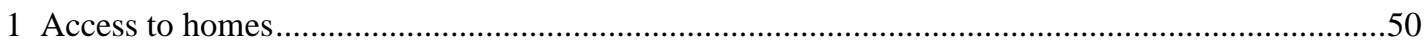

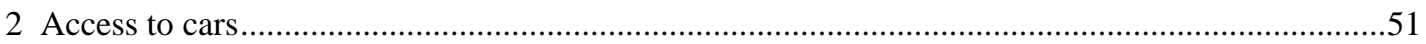

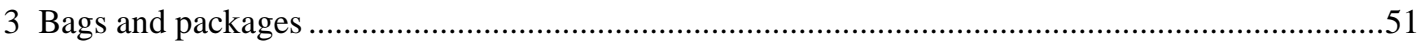

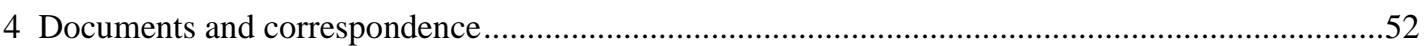

D Is the Filming Occurring in Public Places?...................................................................................52

E The Genre Involves Topics Usually Considered Private................................................56

F The Difficult Situation of Law Enforcement Information ..............................................57

1 Proposition one: there is no general presumption of innocent guaranteeing privacy protections of

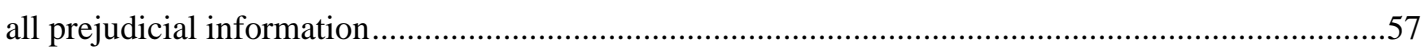

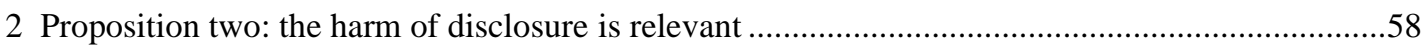

3 Proposition three: the timing of the publication is also relevant .............................................60

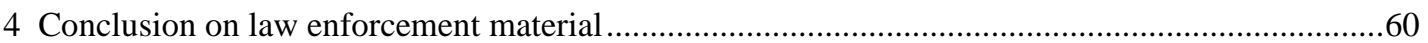

G People Signal Expectations of Privacy .....................................................................................60

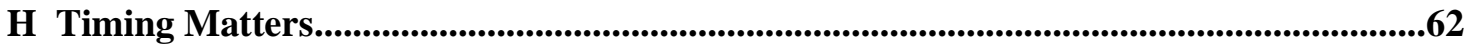

I Conclusion on the reasonable expectation of privacy........................................................62

VII The Broadcast Content is Highly Offensive ...................................................... 63

A The Application of the Highly Offensive Test in Andrews v Television New Zealand .64

B The Core of the Test is Degrading or Humiliating Coverage ...............................................65

C Humouring Involuntary Participants..............................................................................................66

D Humiliation and Degrading Coverage............................................................................................67 


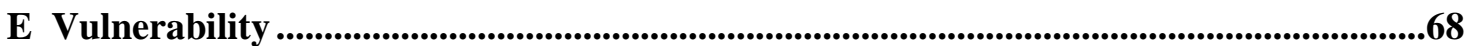

F Offensiveness as a Result of the Collection.............................................................................69

G Offensiveness Explored: Ali v Channel 5..............................................................................69

VIII The Breach is Not Answered by Any Defence .................................................... 72

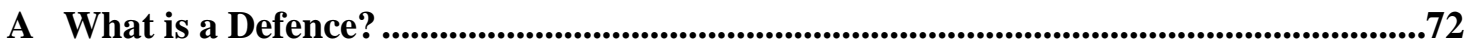

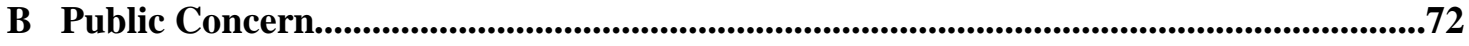

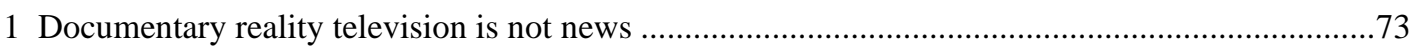

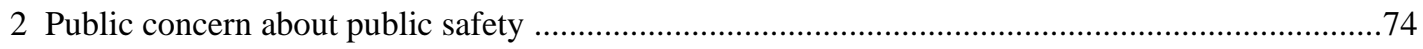

C The Basis Illegality as a Defence ...................................................................................................75

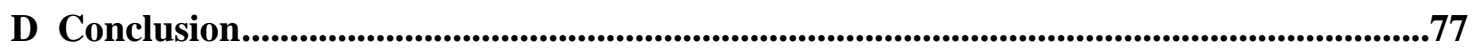

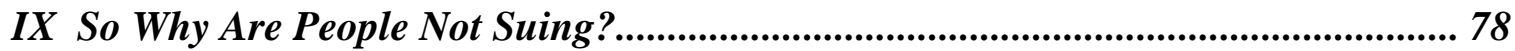

A Returning to Ali v Channel 5 .................................................................................................78

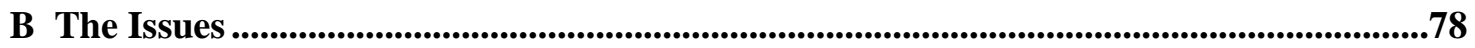

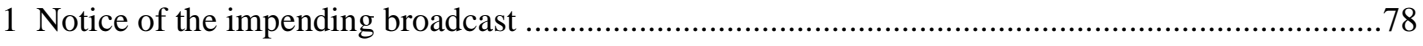

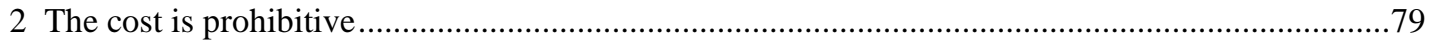

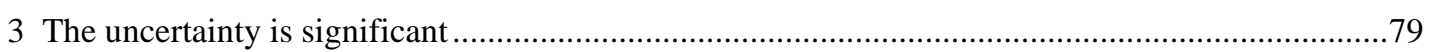

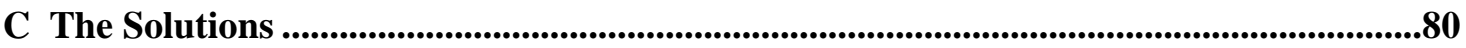

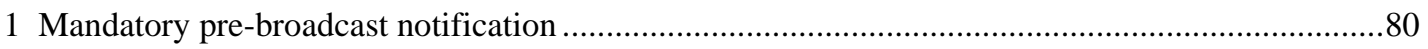

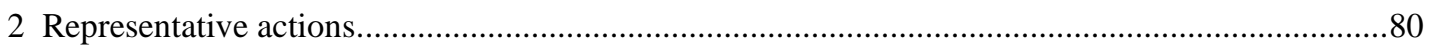

3 Increase the remedial powers of the BSA and introduce own motion powers .................................82

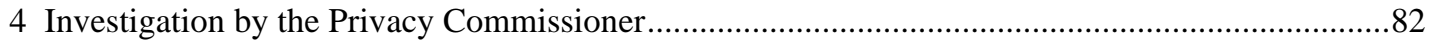

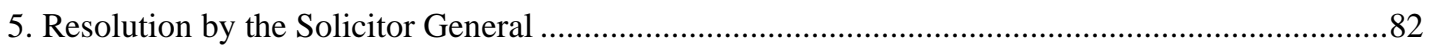

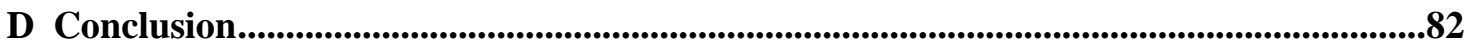

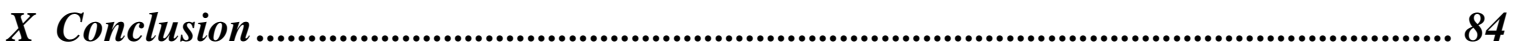




\section{Abstract:}

Documentary reality television is hugely successful. The genre, which includes shows like Police Ten 7, Coastwatch and Border Patrol, consistently outperforms other television formats and fills free-to-air television schedules. In these shows ride-along film crews and body-worn cameras record agencies as they go about their tasks. Often these agencies are public authorities and their tasks are statutory functions. The purpose of this paper is to examine the genre's privacy implications. It concludes that the genre is systemically unlawful. It is unlawful because it breaches the privacy rights of involuntary participants. The paper considers the privacy implications by examining the genre against the shared features of the publication tort and the Privacy Broadcasting Standard. Both of these consider that it is a breach of privacy to broadcast material subject to a reasonable expectation of privacy, where that broadcast is highly offensive unless there is an applicable defence.

While the material broadcast represents the work of agencies, it also represents the personal stories of everyday people going about their lives. Often the moments captured are significant life events and intimate moments for those people. By agreeing to contribute to the genre, agencies agree to broadcast these life events without the active involvement of the participants. Research has also found that this is often occurring without informed consent. While the focus of this paper is on the private law implications of the genre, it identifies that some public authorities' involvement in the genre may also be ultra vires. The paper finishes by considering why, if the genre is systemically unlawful, people are not suing. It considers that general issues with access to civil justice and the powers of the Broadcasting Standards Authority stand in the way of potential complainants. It finishes by considering some solutions that could improve the situation.

Word Length: The text of this paper comprises of 34,972 words including footnotes.

Subject and Topics:

Privacy

Reality television

Reasonable expectation of privacy

Law enforcement

Highly offensive publication

Publication tort 


\section{Introduction}

A teenager was enjoying a day at Bondi Beach before she was caught in a current and swept from the shore. To make matters worse, a friend had stolen her bikini top, leaving her topless. A lifeguard proceeded to her with rescue equipment and a camera. The encounter was filmed and broadcast on Bondi Rescue. ${ }^{1}$ The broadcast even included the moment that she initially refused to get onto the rescue equipment due to the camera pointing at her within arm's reach.

A man was accused of selling cannabis. ${ }^{2}$ The Police approached his family home and executed a search warrant. Police Ten 7 followed and recorded the events. While the man's face was pixelated, the encounter was broadcast identifying his home, health concerns and his circumstances to his small community.

These are just two of the experiences in the growing media back-catalogue. Indeed, it is perhaps difficult to imagine an experience that cannot be observed in modern entertainment. From birth $^{3}$ to death ${ }^{4}$ (including suicide), ${ }^{5}$ cameras have recorded everything from weddings, ${ }^{6}$ to car crashes, ${ }^{7}$ to being mauled by polar bears. The media's pervasive reach is a matter of supply and demand; rather than set piece drama shows, viewers are choosing media which presents authentic human experience. Reality television is mainstream media's response to this desire.

\footnotetext{
* Enrolled Barrister and Solicitor of the High Court of New Zealand. The contents of this paper are my own and do not represent the views of any associated entity, employee or client. This paper would not have been possible without the encouragement and support of my supervisor, Professor Nicole Moreham. Thank you Katrine for encouraging me to start, Anna for supporting me throughout and to Amy and Shaun for supporting me through to the finish.

1 "Bondi Rescue" (2011) Cordell Jigsaw Productions, season 6 episode 8.

${ }^{2}$ MA v Television New Zealand BSA Decision No 2010-084, 22 February 2011.

3 "The Business of Being Born" (2008) Barranca Productions.

4 "The Bridge" (2006) IFC Films. The Bridge could justify a thesis on its own. It filmed the Golden Gate Bridge for a year to bring attention to suicide. They interviewed the people impacted by the suicides off the bridge. While it is available online, absolute discretion is advised.

5 "Time of Death" (2013) Showtime.

6 "Married at First Sight" (2014 - present) Warner Brothers.

7 "Police Ten 7" (2002 - Present) Screentime.
} 
This paper concerns the privacy implications of a subset of reality television referred to as documentary reality television. In these shows a film crew or body-worn cameras record an agency as it goes about its work. The recorded material is then used to create entertainment television, often with the agency providing commentary and background information. This genre includes shows like Police Ten 7, Motorway Patrol and Coastwatch.

This subset of reality television is noteworthy because often the filming occurs when an agency is acting towards some public function. As will be discussed later on, the statutory authority for this role is unclear and may be ultra vires. Examples include law enforcement, rescue attempts and medical care, which are all broadcast for reality television. The stories broadcast therefore include the stories of everyday people going about their lives. This broadcast raises significant questions about the privacy rights of those participants.

These involuntary participants are not pre-planned intentional participants who have sought television attention. Instead, they are people engaging public services or receiving public scrutiny, often because they are compelled, because they need help or because they are suspected of wrongdoing. In this way these shows are distinct from other reality television formats such as staged situation (Married at First Sight, Love Island), home video (America's Funniest Home Videos), lock away (Big Brother) or castaway (Survivor) shows. Documentary reality television shows are also distinct from consumer shows like Target and Fair Go, which seek out stories and report on them.

\section{A Why Does it Matter?}

Documentary reality television now fills a substantial amount of free-to-air television schedules, partially because it is commercially successful. To put this success into perspective, in 2015 the largest media event was the Rugby World Cup. The final captured $16.0 \%$ of the New Zealand television audience. ${ }^{8}$ Meanwhile, Border Patrol gained on average $15.3 \%$ over nine episodes. These audience figures offer unparalleled reach into New Zealand households. Broadcasters also favour the genre because viewers between the age of 18 and 34 are overrepresented in the reality television audience, as opposed to the ageing overall television demographics. ${ }^{9}$ This demographic is the most commercially active, which allow broadcasters to charge more for advertising.

This success means production companies get to sell valuable shows and broadcasters get to sell advertising against those show's success. So too, the incentives for public authorities are significant as the genre has become a major channel for agencies to tell their stories and

\footnotetext{
${ }^{8}$ Nielson "Media Trends 2016" (June 2016) < https://www.nielsen.com> at 22.

9 June Deery "Reality TV as Advertainment" (2004) 2 Popular Communication 1 at 4.
} 
to seek promotion. So much so that the New Zealand Police now have a full time staff member dedicated to managing the demands of reality television. ${ }^{10}$

While the genre is successful, the success is based on the commercialisation of the stories of everyday New Zealanders interacting with agencies. This paper examines the legality of this arrangement with a focus on the privacy rights of the involuntary participants included in the genre. In doing so, it concludes that the genre is systemically unlawful.

The genre is unlawful because it broadcasts content subject to a reasonable expectation of privacy and does so in a way which is often highly offensive. Furthermore, the content subject to a reasonable expectation of privacy is not consistently covered by public concern or any other defence. These three features of the genre are the common core features of a breach of the Privacy Broadcasting Standard and the publication tort. ${ }^{11}$ What makes this illegality systematic is that it is this same access that generates the exclusive content and creates the intrigue in the genre. There are no shows focusing on grocery shopping or commuting to work because reality television requires a level of exclusivity mixed with the reality. In this way, the exclusive access granted to production companies and the entertainment format are the foundations of the genre and the genre's Damoclean sword.

This exclusive access is challengeable because there is a right to privacy in New Zealand. That right to privacy is protected in a variety of ways, by different statutory and private law safeguards. The heart of these safeguards is a normative claim to privacy or the societally enforced "freedom from unwanted access". ${ }^{12}$ In other words, the courts have confirmed that it is the normative claim to privacy which the law ought to protect.

Alongside its illegality, this paper discusses how documentary reality television risks undermining the very same public functions it promotes. For example, recording interactions can interfere with rescue attempts, suspects being forthcoming and cause other deleterious effects.

\section{B Structure}

This paper is divided into two parts; part one establishes the genre, the parties and their motivations. Part two directly considers the privacy implications.

\footnotetext{
10 This information was provided as additional context within a decision on a request for information under the Official Information Act 1982.

${ }^{11}$ Hosking v Runting [2004] NZCA 34; Broadcasting Standards Authority "Broadcasting Standards in New Zealand Codebook" (1 April 2016) at 41.

12 Henderson $v$ Walker [2019] NZHC 2184 at 202 citing N A Moreham "Unpacking the reasonable expectation of privacy test" (2018) 134 LQR 651.
} 


\section{Part one: examining the genre}

Chapter two establishes the genre by tracing its origins and its move to New Zealand. It covers how the genre was formed in the United States of America before expanding to New Zealand at the turn of the century. This means New Zealand received a genre crafted in the context of the American First Amendment. The early New Zealand shows were like their American law enforcement counterparts. However, soon the shows took on a uniquely New Zealand format, with Border Patrol and Piha Rescue. These shows stretched the boundaries of the genre and the agencies involved.

Chapter three establishes the parties to the genre and their relationships. First, it considers the relationship between the production company and the agency, that is the most formal of the relationships. Second, the chapter examines the relationship between the agency and the participants. It does so considering traditional protections surrounding information gathered for public functions. Extending back to Entick $v$ Carrington it has been acknowledged that the pervasive and coercive powers of the state to collect information should be tightly prescribed so as to protect individuals. ${ }^{13}$ Documentary reality television contrasts this traditional relationship of protection; instead of protection, individuals are filmed and their stories are broadcast for commercial purposes.

Chapter four considers whether the agencies profiled in the genre risk being joined to the proceedings contemplated in part two. Building on the analysis of the prior chapters, the chapter concludes that the substantial contribution made by these agencies exposes them to liability for the breach of privacy.

\section{Part two: the privacy implications of the genre}

Chapter five provides the framework for analysing a breach of privacy which is used throughout the remainder of the paper. It does so based on the three shared requirements for a breach of privacy in tort and the Broadcasting Standards. If these three elements are met then a broadcast can be said to have been a breach of privacy. The first element required is that a broadcast publishes material subject to a reasonable expectation of privacy. The second element is that the published material is highly offensive. The final element is that the publication is not justified by any defence. The principal defence is that the publication of the material is in the public interest.

Chapter six transitions to the first element of the liability framework by discussing how documentary reality television broadcasts material subject to a reasonable expectation of

${ }^{13}$ Entick v Carrington [1765] EWHC J98 (KB). 
privacy. Much material broadcast in the genre falls within categories of material which in other settings have been considered putatively private. These include spatial categories, such as people's homes and cars, along with information categories, such as health information and law enforcement information. Broadcast Standard Authority research supports that these privacy expectations are not consistently answered by the consent of the parties. This means that a reasonable expectation of privacy typically exists.

Chapter seven concerns the second element of the framework: that the broadcast of the material frequently meets the highly offensive standard. What is highly offensive is notoriously difficult to define. Indeed, a review of authority reveals judges rarely dwell on the concept and assign it to the category of 'judicial instinct'. ${ }^{14}$ Difficult as it may be, category defining examples of highly offensive publication are humiliating and degrading content, and the genre strays into this territory. Participants are mocked and ridiculed. However, even when the material itself is not degrading or humiliating, the contextual factors underlying the relationship with the agency often result in high offensive publication. This is particularly acute when the involuntary participant is trapped, requires aid or is compelled to engage with the agency.

Finally, the paper considers whether the genre is justified by any defence, principally the defence of public concern. Chapter eight argues that it is not. It is broadly accepted that not all publications of private material should be actionable. Indeed, some are justified by public concern, particularly in the context of the considerable importance of freedom of expression. It is also broadly acknowledged that there is a hierarchy of freedom of expression; expression such as political speech is, for example, afforded greater protection than commercial publication and gossip. High in this spectrum is news activity, which documentary reality television is sometimes said to be. Chapter eight argues that documentary reality television is not news content and, in fact, has many features entirely opposed to news content. Examples include the syndication and rebroadcasting of content. The chapter concludes that there is a public concern interest in the genre, but that it is inconsistent and will often be complicated by the additional entertainment purpose motivating the final broadcast. It closes by considering other applicable defences.

Having concluded that many of the genre's core features meet the three elements for liability, chapter nine moves to answer the obvious ensuing question, why are people not suing? It does this by considering the options and the remedies available. In doing so it provides an explanation as to why the genre has continued to be unregulated. This is because each of the options available have distinct and significant drawbacks. The cost of litigation and uncertainty of the tortious action stifles the benefits of private law action and

\footnotetext{
${ }^{14}$ N A Moreham "Abandoning the Highly Offensive Test” (2018) 4 CJCCL 1 at 15.
} 
the low maximum award renders the Broadcasting Standards Authority (BSA) unable to regulate the genre. As such, this paper concludes by arguing that systemic inquiry either by the Privacy Commissioner or the court is required to address the genre. Simultaneously, the Crown should consider its involvement in the genre. 


\section{What is Documentary Reality Television?}

This chapter concerns the history of documentary reality television and its introduction to New Zealand. It presents documentary reality television as a cohesive genre capable of analysis.

\section{A The Origins of Documentary Reality Television}

Reality television has had a profound effect on television broadcasting. There is a broad acceptance that it is here to stay. What is less clear is when it started or why it has taken such a hold.

One origin story places reality television's genesis with Candid Camera in $1948 .{ }^{15}$ Candid Camera was a situational comedy which set up real people, not actors, in comedic situations and recorded it on hidden cameras. As tension rose to a crescendo, the presenter, Allen Funt, would come forward and say his famous line: "Smile! You're on candid camera." The segment was a commercial success, and the format continues to this day with shows such as What would you do, Punk'd, and Betty White's Off Their Rockers. New technology and discrete cameras enabled the show by allowing film crews to venture outside of the confines of a studio and set-piece dramas.

While Candid Camera involved unprompted people, the show placed them into staged situations with actors and scriptwriters. For this reason, Michael McKenna places the origin point of reality television as the National Broadcasting Company's (NBC) Real People in 1979. ${ }^{16}$ Real People was a panel show where the panel reacted to the pre-recorded lives of everyday people who would not usually be the subject of television shows of the day. Unexpectedly, it rose to become the best performer in its competitive segment. ${ }^{17}$

McKenna argues that the success of Real People was due to its presentation of uncommon but not unusual people. ${ }^{18}$ This, he attributes, to the successes of future shows such as Deadliest Catch, Dirty Jobs, and Duck Dynasty. But, like with Candid Camera, the shows still had elements of staging and preparation, unlike the reality television shows to come. Participants were engaged in production and interviewed.

\footnotetext{
${ }^{15}$ Annette Hill Reality TV: audiences and popular factual television (Routledge, London, 2005) at 21-23.

${ }^{16}$ Michael McKenna Real People and the Rise of Reality Television (Rowman \& Littlefield Publishers, Maryland, 2015).

${ }^{17}$ At 7.

${ }^{18}$ At 23.
} 
By the summer of 1980 things were going badly for the television industry. Two prominent actors' unions had gone on strike, leaving broadcasters without content. ${ }^{19}$ This benefited Real People, because it did not use actors. Moreover, the American economy was struggling, and world politics were unsettled. These were significant issues for the country. McKenna argues that the everyday nature of Real People contrasted the era by providing hopeful stories of ordinary lives. ${ }^{20}$

The summer of 1980 also benefited another show, Speak Up, America, which was also unaffected by the strike. The show was similar to Real People; however, instead of presenting their lives, people gave their views and opinion. It tackled difficult topics such as drugs, war and the economy. But, unlike other shows of the day, the views were not those of scholars or public authorities. Instead, they were the views of everyday people encouraged to share their opinions. ${ }^{21}$ Its stated purpose was to speak truth to power. Immediately the show was criticised for being irreverent and for presenting unqualified opinions. One review, titled "Keep Quiet, "America", said: [w]atching the program is like being trapped on a street corner with an expostulating wino". ${ }^{22}$ The lack of expertise and balance raised issues around the broadcasting standards of accuracy and fairness. ${ }^{23}$ This concern materialised in at least one defamation claim for a statement made by an audience member. ${ }^{24}$ Reviewers criticised the people, opinions and format of the show. It was not just said to be bad, it was "positively frightening". 25

While short-lived, the Speak up, America was an early attempt at dealing with difficult topics in a new format by hybridising documentaries and entertainment. It represented a desire to move difficult topics away from the sole domain of experts and established commentators, and to present realism, relatable people and normalcy.

What came next however cemented the place of hybrid documentary television, with the release of Cops in 1989. A film crew recorded the show by riding along with police officers. Cops presents a binary world, its theme song is Bad Boys, and these 'bad boys' are juxtaposed with the 'cops' who are the heroes of the show. The show is simple and approachable. Indeed, its presentation is not far removed from a game of 'cops and robbers'. In the words of one reviewer, ${ }^{26}$

\footnotetext{
${ }^{19}$ McKenna, above n 16, at 33.

${ }^{20}$ At 36.

21 At 45.

22 Tom Shales "Keep Quiet, 'America"” Washington Post (America, 1 August 1980) available online at <https://www.washingtonpost.com>.

${ }^{23}$ McKenna, above n 16, at 46.

${ }^{24}$ Dymond v National Broadcasting 559 F Supp 734 (D Del 1983).

25 Tony Schwartz "George Schlatter Finds The Fun In TV” New York Times (New York, 6 May 6,1982).

${ }^{26}$ Willie Versteeg "Everyone Should Be Watching the Reality Show Cops Right Now. Seriously." Slate 8 March 2016 <www.slate.com>.
} 
Here are the brave men and women who keep us safe. There are the bad guys. Now watch your tax dollars at work as Group A chases after and tackles Group B.

As like Speak up, America the show deals with difficult issues, but instead of presenting the audience with topical issues, it gave them crime stories, marking the debut of law enforcement reality television.

Cops was soon joined by Rescue 911, On Screen: Emergency Rescue and Real Heroes. Not only is Cops still broadcast today, but many New Zealand reality television shows have adopted the format, including Police Ten 7, Motorway Patrol, Dog Squad, Coastwatch and Border Patrol. A version of the format follows rescue services, such as Piha Rescue, Firefighters and Rescue 1.

Unlike Speak Up, America the critical reception to Cops was muted. It was not acclaimed or damned by critics. It was not a rating topper or a failure. This may be because, while Speak Up, America was about speaking truth to power and anti-authority, Cops supports existing power structures and provides a pro-police message with patriotic undertones. ${ }^{27}$ While Cops and related shows avoided the controversy of Speak up, America, the merging of documentary and entertainment television did create some controversy.

\section{Ayeni $v$ CBS}

In March 1992, Secret Service Agents entered the home of Mr Ayeni, in New York. ${ }^{28}$ Authorities suspected Mr Ayeni of credit card fraud and the Secret Service had a search warrant for his home. A CBS film crew accompanied the Secret Service, recording a segment called Street Stories, which focused on street crime. One officer wore a recording device so he could provide a running commentary of the search. Mr Ayeni was out, but his wife and child were home. Mrs Ayeni asked not to be filmed, but the cameras roved through the house taking close up video of them and their possessions. The search uncovered no evidence. Despite the lack of evidence, a Secret Services agent made many repeated assertions to the camera that Mr Ayeni was guilty. In the resulting criminal proceedings, the judge referred to the search as an abuse and demanded for the tapes to be turned over to the court. ${ }^{29}$ The judge noted that, ${ }^{30}$

Because the press in certain circumstances may be able to resist the demands of a subpoena, does not mean the press may, simply by raising the cry of "newsgathering," exempt itself from all ordinary legal constraints.

\footnotetext{
${ }^{27}$ Which led some to question whether the sub-genre would survive the 2010's discussion of the police and police brutality. See: Max Kutner,"Will 'Cops' Survive the Turned Tide on Police Videos?" Newsweek 17 July $2015<$ Newsweek..com>.

${ }^{28}$ Ayeni v CBS 848 F Supp 365 (1994, EDNY).

${ }^{29}$ United States v Sanusi 813 F Supp 149 (EDNY,1992).

${ }^{30}$ At 151.
} 
In proceedings against the media organisation, the judge made passing comments about the government's actions, saying: ${ }^{31}$

The dispute at issue here is between the defendant and CBS. The government's role, however, cannot be ignored. CBS, though it exceeded the permissible scope of its privilege, was engaged in the zealous pursuit of news and profit to which it was properly devoted. The government's obligations are of a different kind. Charged as they are with the delicate and sensitive responsibility of executing a judicially sanctioned violation of a person's privacy, government agents have a duty to see that as little harm is done as is necessary to the task. Wantonly exceeding the scope of the warrant would represent a failure to perform that duty. Inviting private citizens whose presence is not necessary to the execution of the warrant to join the search party is a failure of public turnstone that indicates a disregard of the important values at stake when the government enters a person's home.

\section{Berger $v$ Hanlon}

In 1993, another show focused on the United States Fish and Wildlife Service. Mr Paul and Mrs Erma Berger lived on a remote ranch. They were aged 71 and 81 and neither had criminal histories. The Fish and Wildlife Service suspected Mr Berger was poisoning eagles. They obtained a search warrant and CNN filmed the ensuing events. CNN also had access to the sealed warrants and the pre-search briefing. ${ }^{32}$

Around 30 law enforcement officials in trucks converged on the property. The convoy was so substantial and conspicuous that neighbours called the Bergers to forewarn them. CNN cameras filmed the search with an agent wearing a microphone for commentary. The officials spoke assuredly of the Berger's guilt. While the search warrant excluded the Berger's home, Mr Berger was told that if he did not voluntarily allow the search of his home that he would be taken into custody, so CNN cameras entered there too. The search took 10 hours and found no evidence of Mr Berger poisoning eagles. At trial, Mr Berger was acquitted of killing the eagles. ${ }^{33}$ Regardless, the broadcast repeatedly implied $\mathrm{Mr}$ Berger's guilt.

The Berger's sued, unsuccessfully at first, but successfully on appeal; the Court ruling the search unconstitutional. ${ }^{34}$ The Court also found that by acting as a joint party, CNN had made itself a government actor and liable to constitutional remedies. ${ }^{35}$ While the Berger's succeeded, the individual agents also succeeded in claiming qualified privilege, so were not liable. ${ }^{36}$

\footnotetext{
${ }^{31}$ At 161.

${ }^{32}$ Berger v Hanlon 129 F 3d 505 (9th Cir, 1997).

${ }^{33} \mathrm{Mr}$ Berger was convicted of one count of using pesticide in a manner inconsistent with its label.

${ }^{34}$ Berger, above n 32, at 508.

${ }^{35}$ At 515.

${ }^{36}$ Equivalent to crown immunity.
} 


\section{Marichs $v$ QRZ Media}

In 1996, the Los Angeles Police Department responded to an emergency call. It was joined by a film crew recording LAPD: Life on the Beat. ${ }^{37}$ At the scene they found the body of Michael Marich who had died surrounded by alcohol and drug paraphernalia. The film crew recorded his body bent over topless on the floor. The police called his parents to notify them of his death. Initially Mrs Marich rebuffed the call, thinking it was a sales call, until they told her "[w]ell, your son is deceased". She was unaware the film crew were present and picking up the audio of her grief.

The Marichs pursued legal action. At first they failed due to California's procedural first amendment protections and $\$ 66,456$ of costs were awarded against them. ${ }^{38}$ They lost a further appeal in 1999. The case turned on whether the videotape contained personal information about the parents as Michael's privacy rights extinguished on death. Ultimately, the court ruled that the parents' side of the conversation was merely "emissions of sound" incapable of supporting a privacy claim. Finally, in 2003, they successfully appealed, but by this time the production company had filed for bankruptcy. ${ }^{39}$ There are no further reported decisions.

These three cases, Ayeni, Berger and Marich show the early struggle with the new genre. At this time, other cases called into question the broader role of media involvement in public functions. For example, a film crew accompanied an ambulance entering a home to care for a person having a heart attack and then broadcast the footage. ${ }^{40}$ Elsewhere, a mother, who was away visiting a friend, learnt of her daughter's death when a morning paper publishing a story of a fire at her house with a picture of the child-sized silhouette left on the floor under the title "Silhouette of death". ${ }^{41}$ The photo had been taken by a "ridealong' journalist who had accompanied the fire inspector through the burnt house.

While the legal debates occurred, concurrently there were academic debates about the presentation of law enforcement on television. ${ }^{42}$ Particular concerns were that depictions

\footnotetext{
${ }^{37}$ Marich v MGM UA Telecommunications 113 Cal App 4th 415 (Cal Ct Capp, 2003).

${ }^{38}$ California has Anti-SLAPP legislation intended to avoid strategic use of litigation to seek settlement of disputes that would otherwise fail due to First Amendment protections. See Kathryn Tate, "California's Anti-SLAPP legislation: a summary and a commentary on its operation and scope” (2000) 4 Loyola Law Review 1.

${ }^{39}$ Marich v MGM UA Telecommunications 113 Cal App 4th 415 (2003).

${ }^{40}$ Miller v National Broadcasting Company 187 Cal App 3d 1463 (1986).

${ }^{41}$ Fletcher v Florida Publishing 319 Sup 2d 100 (Fla Dist Ct App, 1975).

42 See: Elizabeth Monk-Turner and others "Are reality TV crime shows continuing to perpetuate crime myths" (2007) Internet Journal of Criminology. Paul Mason Criminal visions media representation of crime and justice (Cullompton, Devon, 2003). Paul Kooistra, John Mahoney and Saundra Westervelt (1998) "The World of Crime According to 'Cops"' in G Cavender and M Fishman (eds) Entertaining Crime: Television Reality Programs (Aldine De Gruyter, New York, 1998) 141.
} 
of minority groups committing crime were overrepresented, authorities were represented as more diverse than they were and that there was a disproportionate focus on street crime. ${ }^{43}$ Additionally, this research also raised concerns that footage demonstrated law enforcement was more likely to escalate physical contact and use violence than was reported. ${ }^{44}$ This conclusion raised concerns whether law enforcement was playing up for the spectacle to create compelling television and this could be leading to an unnecessary escalation in violence, or that the recordings demonstrated underreporting of escalated interactions.

\section{B Documentary Reality Television Arrives in New Zealand}

At the turn of the millennium, reality television started to appear in New Zealand, led by Popstars, ${ }^{45}$ Pioneer House ${ }^{46}$ and Motorway Patrol. ${ }^{47}$

In September 1999, Motorway Patrol launched law enforcement television in New Zealand. Produced by Greenstone TV Limited, the show depicts the work of the Police working on New Zealand's roads. It includes traffic violations, accidents and the search for illegal substances. Two years later, Police Ten 7 launched. The show joins the New Zealand Police for real police patrols. The name comes from New Zealand police's code for arriving on to a callout 10-7. Unlike Cops, Police Ten 7 also relies on reconstructions, a narrator and sometimes identity images of offenders that the public are asked to identify.

Both Police Ten 7 and Motorway Patrol have been successful and exist to this day. While these shows have unique elements, they are also similar to the American shows that preceded them. However, the release of Border Patrol changed this, with a markedly New Zealand show focusing on the unique New Zealand border. Border Patrol was a quick hit and also continues today.

The show's genesis in New Zealand makes sense given New Zealand's sophisticated and risk-adverse border protection design, with some of the toughest biosecurity protections in the world. The show was also successful overseas, being screened in multiple countries. ${ }^{48}$ To put its success in perspective, in 2013, MediaWorks and TVNZ were both competing heavily for the $7 \mathrm{pm}$ slot with high budget live television. Both shows - and Shortland Street - failed to outperform reruns of Border Patrol. ${ }^{49}$ While reporting on the "baffling"

\footnotetext{
43 Mary Beth Oliver "Portrayals of crime, race, and aggression in "reality-based" police shows: A content analysis" (1994) 38(2) Journal of Broadcasting \& Electronic Media 179.

44 See footnote 42.

45 "Popstars" (1999) Screentime.

46 "Pioneer House" (2001) Touchdown Productions.

${ }^{47}$ Motorway Patrol (1999) Greenstone TV Limited.

${ }^{48}$ Including Australia, the United Kingdom, Sweden, the United States, Ireland, Denmark, Norway and Italy.

${ }^{49}$ Chris Keall "Seven Sharp in ratings tailspin/On human bondage" National Business Review (08 Feb 2013) <www.nbr.co.nz>.
} 
ratings one review describes Border Patrol as "a lame reality show with an uninteresting setting and the most repetitive formula on television". 50

\section{New Zealand's Muted Discussion}

While, it has been criticised as bad television, representing the "dumbing down" of entertainment, reality television has captured a significant part of New Zealand's television schedule. ${ }^{51}$ There have, however, been challenges including BSA complaints and Andrews $v$ Television New Zealand, in the High Court.

In particular, three BSA complaints have focused on Dog Squad, which is a documentary reality television show focusing on Corrections, the Police, Civil Aviation and Customs New Zealand's use of working dogs. The opening monologue states:

At airports, prisons and throughout our communities, a small squad of dedicated dog handlers work around the clock fighting crime, saving lives and combating the work of some of the country's most dangerous and notorious criminals.

In DS and Television New Zealand a person complained about being placed alongside New Zealand's most notorious criminals. They just wanted to get to a party. Regrettably for them, they took a wrong turn and ended up on the road to Waikeria Prison. A dog sniffed the car and made a positive indication for drugs, an unidentified object was removed and DS was issued a trespassed notice from the prison. The footage of the search was broadcast on Dog Squad. DS's complaint to the BSA, was successful and received $\$ 750$ compensation.

In $P N$ and Television New Zealand, a Quarantine Officer for Customs New Zealand complained that his privacy had been impacted when he was identified questioning passengers entering Auckland Airport. ${ }^{52} \mathrm{He}$ had requested multiple times not to be identified in the show. The Authority held that PN had no reasonable expectation of privacy in a busy airport carrying out his role and therefore it did not uphold his complaint.

In $S W$ and Television New Zealand, a prison visitor was identified improperly and received $\$ 1,000$ compensation. ${ }^{53}$ Television New Zealand claimed that it had her consent, however, the Authority found that her consent was inappropriately gained. She had twice refused consent to be filmed. ${ }^{54}$ Twelve minutes later, surrounded by law enforcement and obviously emotional, she was again asked whether she consenting to being filmed and this time she agreed. She was then followed for a second segment inside the prison, to which

\footnotetext{
${ }^{50}$ Stuff "Baffling ratings at 7pm" (29 January 2013) <www.stuff.co.nz>.

${ }^{51}$ Stuff "The reality of reality - the dumbing down continues" (12 November 2014)<www.stuff.co.nz>.

${ }^{52}$ PNv Television New Zealand Ltd BSA Decision No 2016-041, 15 September 2016.

${ }^{53}$ SW v Television New Zealand Ltd BSA Decision No 2015-030, 18 December 2015.

${ }^{54}$ At [28].
} 
she said she did not consent. Further, she said she never expected, or was told, that any footage was to be screened nationwide on primetime television. ${ }^{55}$

Other television shows have also courted controversy. In an episode of Water Patrol, Maritime Police checked on a person sunbathing in the Marlborough Sounds. He was in a secluded area on his boat when the film crew and Police arrived. As it happened he was sunbathing and not wearing any pants. Maritime Police and the voice narrator comment on his partial nudity, humouring the situation. The occupant complained that the coverage breached his privacy and was successful. ${ }^{56}$ The BSA noted there was no public interest and the clear intention of the interdiction had been to make a funny television segment at the man's expense. The Authority also note that the filming was only possible because of the exercise of the Maritime Police's authority and in other circumstances, no one could have viewed his lower body while below deck. ${ }^{57}$

In yet another broadcast, a rerun episode of one police show, "...the team pay a visit to a habitual solvent abuser" who the broadcast identified. ${ }^{58}$ The Police make a point that they are on a first-name basis with the subject. The footage was a decade old at the time it was broadcast for the third time, and the man said he had given up drugs and moved on with his life. TVNZ was ordered to pay $\$ 1,000$ compensation and another $\$ 1,000$ costs.

Controversy emerged in 2009, when an Immigration Service and Police raid of a brothel was filmed for the show Borderline. ${ }^{59}$ A man leapt from the building, ${ }^{60}$

Witnesses said the 38-year-old man panicked when he heard a commotion as officials and a Cream Media television crew entered the brothel.

The man later died from his injuries. While the Immigration Service did not accept responsibility for the death, former immigration minister Tuariki Delamere accused officials of using unnecessary tactics to produce sensational television.

In 2010, Police executed a search warrant on Police Ten $7 .{ }^{61}$ The occupant was fined $\$ 150$ for possession of cannabis. The man's small town, suburb, street and property were identified. He justified his possession based on medical reasons, which were also broadcast. While his family's faces were blurred, their voices were broadcast unaltered. TVNZ argued that the man had seen the cameras and had not objected, but the Authority did not accept

55 At [29].

${ }^{56}$ PG v Television New Zealand Ltd BSA Decision No 2014-090, 16 June 2015.

57 At [12].

${ }^{58}$ MQ v Television New Zealand Ltd BSA Decision No 011-033, 13 September 2011.

${ }^{59}$ Stuff "Man dies after leap from brothel window" (31 January 2009) <www.stuff.co.nz>.

${ }^{60}$ Stuff "Death after TV brothel raid" (31 January 2009) <www.stuff.co.nz>.

${ }^{61}$ MA v Television New Zealand, above $\mathrm{n} 2$. 
that this met the standard for consent. The BSA ordered TVNZ to pay $\$ 1,500$ compensation and $\$ 1,000$ costs.

However, in the context of an industry measured in the hundreds of millions of dollars per year, the BSA's remedial orders do not pose an existential threat to documentary reality television in New Zealand. This is especially true since the BSA is not governed by stare decisis, so decisions do not develop binding precedent. The one dispute that did pose an existential risk was Andrews v Television New Zealand in the High Court.

\section{Andrew v Television New Zealand ${ }^{62}$}

Mr and Mrs Andrews had been at a party. They had been drinking and were involved in a serious crash. The crash left them stuck in their car upside down some way away from the road. When the fire service arrived Mr Andrews was still trapped in the car and was in shock. Meanwhile Mrs Andrews was pleading for her husband to survive. He was removed from the wreckage using heavy equipment.

Meanwhile, Greenstone TV film crew filmed the chaotic scene for over an hour. The car was surrounded by emergency services and beam lights lighted the scene. Neither Mr nor Mrs Andrews acknowledged the cameras during the recording. ${ }^{63}$ The Police did not prosecute Mr or Mrs Andrews' because they said they could not evidence who was driving. This suggests that even the Police did not recognise the cameras at the scene, because they recorded who was in the driver's seat, indeed it was broadcast on television.

A firefighter, who just moments earlier had been explaining and demonstrating the pranks firefighters played on each other, narrated the crash and the recovery. ${ }^{64}$ While he does not mention alcohol, implicit in his explanation is that it is a significant crash that would be an unexpected outcome of normal driving.

Sometime later, the Andrews were again with friends, when footage of their crash was broadcast in the television show Firefighters. Viewing the footage on television was the first time they learnt they were filmed. They brought proceedings. The case was heard in front of Justice Allan in the High Court who dismissed the case. While he accepted that they had a reasonable expectation of privacy, he found the broadcast was not highly offensive, meaning the Andrew's claim failed. As will be discussed later in chapter seven Allan $\mathbf{J}$ applied a high standard for the publication tort. However, the key point is that the

\footnotetext{
${ }^{62}$ Andrews v Television New Zealand [2009] 1 NZLR 220 (HC).

63 Jennifer Moore "Traumatised Bodies: Towards Corporeality in New Zealand's Privacy Tort Law Involving Accident Survivors" (2011) 24 NZULR 387 at 402.

64 "Fire fighters" (2004) Greenstone TV Limited, series 1 episode 8.
} 
judgment was not a damaging juncture for the genre, where it was critically examined, meaning the genre continues in New Zealand to this day.

\section{E Summary}

This chapter has demonstrated that documentary reality television is a coherent genre capable of analysis. It developed in the United States of America and expanded to New Zealand at the turn of the century. The genre was pre-formed in three decades of experience in America, including a substantial litigation history, defining what could and could not be broadcast. While this meant New Zealand received a commercially successful format, it also received a genre defined by the First Amendment. Cases such as Marichs and Berger shaped the genre, but are based on American legal jurisprudence which is not applicable in New Zealand.

When the shift occurred, New Zealand broadcasters adopted a similar format to American shows. However, soon after they developed something unique with Border Patrol. In part, the distinctive characteristics of New Zealand's border offer a compelling new setting for the genre. It can also be attributed to the New Zealand television market's desire for local content and broadcasters' reduced production budgets. This nexus of desire and budget constraints required creative solutions, leading to New Zealand broadcasters developing unique content. Indeed, in many ways, New Zealand was a world leader for reality television. Border Patrol brought about Nothing to Declare in the United Kingdom, Border Security in Australia, and Homeland Security in the United States of America. Motorway Patrol has been turned into an Australian show, Highway Patrol and two further off-shoots: Outrageous Characters and Worst Drivers. Popstars led to the creation of the successful pop group TrueBliss and was also a format which was sold to multiple countries. It inspired Pop Idol which, in turn, led to the creation of New Zealand Idol, American Idol, and Australian Idol. 


\section{The Parties and Relationships}

This chapter examines the parties involved in documentary reality television, their relationships and their motivations. This provides a basis for considering the privacy implications and liabilities in successive chapters. The first relationship considered is that of the production company and the agency. This is the first relationship because it is the most pre-planned and formal of those involved in the genre. This formality provides the parties with examinable intentions. These motivations are not necessarily observed in the other participants, who are often just going about their day or their work. The second relationship examined is that of these participants with the production. In particular, it considers the standard expectations people have when engaging with public authorities and how documentary reality television contrasts these standard expectations.

The relationship between the production companies and authorising agencies are examined in light of available production agreements and judicial comment. ${ }^{65}$

\section{A The Relationship of the Production Company and the Agency}

The relationship between the production company and the agency is the key relationship for the production of documentary reality television. Without the production expertise and the links to the broadcaster, the agency would not be able to produce the broadcast. Conversely, without the agency, the production company would not have access to the stories that give the media life. In this way, both parties are significantly involved in the production and rely on one another. Because of this mutual reliance, the relationship is often contained in a legal arrangement.

The arrangement is usually shaped around some form of agreement. However, some examples are executed as a deed. ${ }^{66}$ This may be intended to mean that the arrangement cannot be defeated due to a lack of consideration. This could be a legitimate concern for reasons that will be discussed later, however, throughout this chapter it is worth repeatedly

\footnotetext{
65 These agreements include: Border Patrol Series 7 Production Agreement (Obtained under Official Information Act 1982 request to the Ministry of Primary Industries). Motorway Series 18 Production Agreement (Obtained under Official Information Act 1982 request to the Police). Police Ten 7 series 27 Production Agreement (Obtained under Official Information Act 1982 request to the Police). All of the agreements and most of the shows discussed in this paper are produced by Greenstone TV Limited. Greenstone TV is the largest producer of documentary reality television in New Zealand. They produce shows including Border Patrol, Motorway Patrol, Dog Squad and Highway Patrol, amongst others.

${ }^{66}$ For example, the MPI and Greenstone TV Ltd Border Patrol Production Agreement.
} 
returning to the matter of consideration for two reasons. First, because the substantial concessions agencies agree to demonstrates how much authorities are willing to trade for the publicity documentary reality television offers. Second, because the particular types of concessions provided demonstrate the desire for exclusivity and access to unique stories. This access is the subject of part two.

At the highest level, production agreements provide a bilateral arrangement where authorities provide access in exchange for low-risk positive publicity.

\section{Access for the production company}

The first key component is physical access for the production company to film the television show. For example, for the production of Border Patrol the Ministry for Primary Industries (MPI) agrees to allow Greenstone access to "MPI Premises" which is defined to include "any premise controlled (in whole or in part) by MPI whether or not MPI is the legal owner, lessee or licensee of the premise". ${ }^{67}$ This definition is critical due to its specificity of control. It is frequently argued that documentary reality television is filmed in public places. However, production agreements, such as this, undermine this argument by specifying that agencies are providing access to areas in which they exert a level of control. This clause is necessary for the production company because control by the agency could create a risk that the agency could exclude filming. Indeed, for many shows, it is essential because technical and security measures would otherwise render access impossible to secured areas such as airports, police cars and police office spaces.

The second form of access provided is informational and technical access. For example, in the same agreement, MPI is also to assist Greenstone with access to staff, contractors and agents for the production of Border Patrol. In the Border Patrol agreement, this access must be reasonable, but it is not subject to any other limitation. This is replicated across the genre, where staff provide commentary and clarification. This commentary is similar to what was criticised in Ayeni and Berger, in which officers commentated the execution of searches. ${ }^{68}$ This chapter discusses later on that when these staff provide commentary, they take on their own motivations and gain the potential for television fame. They are also disclosing material which is held for public functions, often prescribed by law.

This access is secured by specific arrangements for how notice will be provided for the intention to film. Generally, the agency cannot restrict access unless filming would conflict with security or operation requirements. In the Border Patrol production agreement if MPI does decline access to its premise, it must make reasonable endeavours to provide an

\footnotetext{
${ }^{67}$ Border Patrol Production Agreement, above n 65, at 1.1

${ }^{68}$ Berger $v$ Hanlon, above n 34.
} 
alternative location. This requirement assures the production company of access and allows advanced scheduling of filming days. Finally, the production company's commercial interest would be undermined if the same access was also provided to a competing show, so exclusivity is agreed. For Border Patrol, MPI agrees not to provide assistance for similar productions.

This access agreed in the production agreement has previously caused issues for third parties. The main third parties are employees of the agency and the involuntary participants. For example, in $P N$ and Dog Squad, where the BSA did not uphold a complaint by an employee of MPI who was filmed for a reality television show against his will, the complaint was one of access to an employee. The access which was made to him was likely contained in the production agreement. The Authority acknowledged that his information was broadcast, but decided that he did not have a reasonable expectation of privacy going about his public role. ${ }^{69}$ In this respect, PN has effectively been treated as an involuntary participant with a privacy interest. However, potentially the outcome would have been different if the dispute was pursued as an employment dispute, because MPI effectively agreed to the publication of his information against his objection, which may have been a breach of good faith.

There are also examples where filming captures problematic conduct by officials. One of the more clear examples is targeted Police interceptions being presented as random stops. ${ }^{70}$

The other key third party is the involuntary participants. The principal implications are the privacy implications, that are the subject of part two, but there are also examples which demonstrate that this access is prone to causing confusion about the role of media when filming documentary reality television. For example, a suspect famously has the right not to provide answers which may incriminate him or herself. ${ }^{71}$ However, media organisations are gaining privileged access to subjects who they are interviewing without a clear role. To provide just one example, in an episode a subject confesses to the film crew that he believes that a bike in his possession is stolen. ${ }^{72} \mathrm{He}$ goes on to explain that he will not tell the police that. Participants often appear to feel the need to explain themselves to the camera. This appears to be particularly acute in law enforcement television when the officials leave the film crew alone with the participant. For this reason, further research is needed into the role of media in situ in interviews and the evidentiary implications.

\footnotetext{
${ }^{69} P N \vee T V N Z$, above n 52.

${ }^{70}$ For example, see “ $R B T$ ” (2010- present) Screentime, series 8, episode 4.

${ }^{71}$ Bill of Rights Act 1990, s 23.

72 "Motorway Patrol", above n 47, season 4.
} 


\section{Publicity}

The access requirements place significant requirements on the agency. But in exchange for that access the agency gains publicity. The Border Patrol production agreement specifies this consideration upfront in the purpose section, which specifies that one of the two purposes of the production is to demonstrate the work of MPI.

But the desire for publicity is not absolute, there are multiple safeguards included in production agreements to ensure that the publicity is positive. The agreement allows that during the filming of Border Patrol a member of the MPI Communications Team may escort the film crew. MPI also gains the power to challenge footage that would present MPI in bad light or harm the reputation of the Government. This power is protected through multiple review cycles in which MPI is entitled to check what is proposed for broadcast. ${ }^{73}$ This clause embeds a structural imbalance where participants can be presented in bad light, but authorising agencies cannot. It also undermines the news value of the genre, because the production company is predetermining which stories it will not tell.

The need for these checks and controls is that, like access, the publicity motivation has led to negative outcomes for previous productions. One stark example was the 1982 production of Police, by the British Broadcasting Corporation (BBC). Police was a fly on the wall documentary intended to humanise the British Police. At the time there was a perception that the Police were out of touch with society, so Police was designed to show the Police's positive role in society. An expert criminologist, Roger Graef and a film crew recorded the Thames Valley Police Station for a full year. ${ }^{74}$

One winter evening people settled in to watch the BBC. They watched as a woman entered the police station and said that she had been raped by three men. Three male police officers invited her into a small room and sat her down. One sits across from her two stood over

73 The first stage is an "Initial Assessment" and for the most part specifically concerns whether MPI retrospectively had a reason to stop filming or the footage could give rise to a legal claim. The "Final Assessment" is the approval for the footage. No footage can be screened without sign off, provided MPI does not unreasonably withhold approval. It is agreed that unused footage will be promptly destroyed.

${ }^{74}$ Screenonline "Police $(1982)<$ http://www.screenonline.org.uk/tv/id/464502/index.html> 
her informally blocking the exit (image in footnotes). ${ }^{75}$ What happened next changed sexual assault policing in Britain: they yelled at her, attacked her credibility and her story, they suggested she consented, questioned her menstrual cycle and how many men she had slept with, delved into her mental health and repeatedly called into question her efforts to escape. ${ }^{76}$ The clip ended when a Police Officer asked her, "Do you or do you not want to make a complaint of rape?", she replies "No, I do not".

There was widespread condemnation of the show, including criticism from the then Prime Minister Margret Thatcher. ${ }^{77}$ One police officer claimed that he had to move house after the screening and another threatened legal action if it was ever rescreened again. ${ }^{78}$ The episode was so controversial that BBC is said to have locked away its only copy of the tape under a note forbidding its release. ${ }^{79}$ While Police won a BAFTA, the series has never been rerun.

Examples such as Police demonstrate the complex natures of publicity for agencies and the concern for positive publicity.

\section{What is missing from the agreement?}

While the agreements contain legal safeguards, they are targeted at protecting the parties, not the involuntary participants. Examined examples of the contracts for Motorway Patrol, Border Patrol, and Police Ten 7 all specifically exclude the Contract (Privity) Act 1982. This means that prima facie no safeguard in the agreements could be enforced by an involuntary participant of documentary reality television. Indeed, no agreement provided safeguards enforceable by involuntary participants.

\footnotetext{
75 "Police" (1982) BBC. Figure 1:

[Redacted due to copyright]

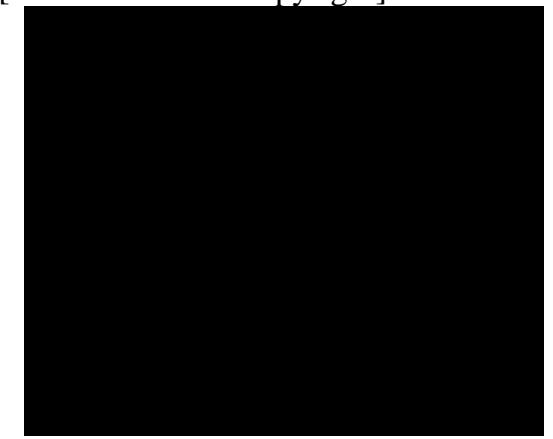

${ }^{76}$ A partial transcript is available in Maggie Wykes and Kirsty Welsh Violence, Gender and Justice (Sage Publications, California, 2009) at 77-78.

77 “Thatcher joins in rape controversy" UPI (London, 19 January 1982).

${ }^{78}$ Guy Davies "Watching the Detectives” Independent (London, 7 September 1999).

${ }^{79}$ Ibid.
} 
Another matter missing from the agreements examined is any exchange of money. This demonstrates the value that agencies are placing on the publicity they receive. An exception is Piha Rescue, where the Piha Surf Rescue Club has acknowledged it received some payment for its involvement in Piha Rescue. ${ }^{80}$ The lack of any other consideration could leave the contracts prone to challenge. This is for two reasons. First, because the publicity received by agencies is a product of the production, not something actually exchanged by the production company. Second, because unless publicity is linked to a statutory function of a public agency, it is doubtful if an agency can bind itself for that consideration.

\section{Conclusion on the relationship with the agency}

The relationship between the production company and the authorising agency is mutually beneficial. The relationship is usually structured in some form of legal agreement setting out the formalities of how the parties will interact and the purpose of the production. These agreements reveal that agencies are playing significant roles in the creation of the broadcast. These roles include allowing access for filming and creating the scenarios that are broadcast. They also agree to commercial terms, such as exclusivity and transfer of intellectual property.

\section{B The Relationship with Involuntary Participants}

While the relationship with the agency is intentional, structured and formal, the relationship with the participants is usually spontaneous. ${ }^{81}$ Participants are not setting out for television fame or recognition, but are instead going about their affairs while interacting with different authorities. They could be a person entering the country (Border Patrol), who has crashed their car (Motorway Patrol) or who requires first aid (Rescue One). While those participants may not have legal safeguards or rights under the production agreements, these are traditionally protected encounters.

Extending back to the famous case of Entick $v$ Carrington, there has been a recognition of the need to limit the powers of the state to collect information. ${ }^{82}$ This is particularly true where some form of compulsion requires the collection. The judgment in Entick $v$ Carrington is notable for its robust protection of the inviolability of a person's home, but also the additional safeguards against collection by public authorities. It famously

\footnotetext{
80 "Beach feud flares at Piha" NZHerald (Online edition, 18 March 2012). Multiple requests were made of Piha Rescue Club for a copy of the production agreement, however, no information was forthcoming.

${ }^{81}$ It is acknowledged that some participants do actively seek out attention, however these examples are the exception not the rule.

${ }^{82}$ Entick v Carrington, above n 13.
} 
reinforced the position that an individual is free to do what is not prohibited by the law, whereas public authorities are only free to act within what the law allows. ${ }^{83}$ That is that “... the executive may do nothing without clear legal authority first permitting its actions". ${ }^{84}$

This means while there is often no contractual arrangement, there is still a legal relationship and it is usually one where the collection, use and disclosure of information is tightly prescribed. Not only do examples such as the Immigration Act 2009, Search and Surveillance Act 2012 and the Postal Services Act 1998 exemplify the (often onerous) need to safeguard people's interactions with the state, personal interactions taken in furtherance of public duties are prima facie confidential. This protection, referred to as the Marcel Principle, specifies that information collected in the furtherance of public duties prima facie has a quality of confidence that should be protected. ${ }^{85}$ This protection is recognised because "[t]he parties are forced into the relationship by statute law". ${ }^{86}$

The Marcel Principle is justified by the extraordinary powers of the state to compel the provision of information. These powers "constitute fundamental infringements of the individual's immunity from interference by the state". 87

The lack of free-market competition also justifies the Marcel Principle. A person who is upset with Nike can choose to wear Adidas. However, a person lost at sea does not choose their rescue helicopter and a person at the border does not choose which customs service they use. The lack of options for public services means that a person unhappy with one agency cannot select another agency or avoid that agency without avoiding those services altogether. Finally, the obligations of confidence protects regulatory systems, because people are more likely to trust and disclose information to entities they believe will hold their information in confidence.

So a person engaging with an authority in furtherance of some public function can expect a degree of protection for the information they disclose. This is relevant because if a person can reasonably expect protection of a class of information, then their reasonable expectation of privacy is increased.

\footnotetext{
${ }^{83}$ At 817.

${ }^{84}$ A Tomkins, Public Law (Oxford, Oxford University Press, 2003) 78.

${ }^{85}$ Marcel $v$ Commissioner of Police of the Metropolis [1992] Ch 225; $R$ (Ingenious Media Holdings plc) $v$ Revenue and Customs Commissioners [2016] UKSC 54; [2016] 1 WLR 4164at [23]; adopted in ANZ Bank New Zealand Ltd v Financial Markets Authority [2018] NZHC 691. With respect to law enforcement see: Brown v Attorney-General [2006] DCR 630.

${ }^{86}$ Smith Kline and French Laboratories v Attorney General [1989] 1 NZLR 385.

${ }^{87}$ Marcel $v$ Commissioner of Police of the Metropolis, above n 85, at 234.
} 
The Marcel Principle has recently received a revival with the English case Ingenious Media $v$ Her Majesty's Revenue and Customs Service. ${ }^{88}$ The case concerned an "off the record" interview given to newspaper media by a senior Her Majesty's Revenue and Customs Service (HMRC) employee, Mr Hartnett. In the interview, Mr Hartnett talked about Mr McKenna, the founder of Ingenious Media, a company which ran a film investment tax scheme. ${ }^{89}$ Some of what Mr Hartnett said was complimentary; he said he was "clever" and an "urbane man". However, Mr Harnett went further, discussing how Mr McKenna was a "big risk" for tax affairs, going so far as to call Mr McKenna a scoundrel offering "scams for scumbags". He said HMRC considered Mr McKenna's company to be a £5bn tax avoidance scheme. The content of the interview was used in two articles published in The Times newspaper.

Initially Ingenious Media challenged the decision to proceed with the interview through judicial review proceedings. Both the High Court and Court of Appeal dismissed the application. They ruled that Mr Harnett's decision to proceed with the interview was not so unreasonable to be reviewable.

The matter then proceeded to the Supreme Court. The Supreme Court found HMRC breached its duty confidence in the interview. Dismissing the earlier decisions, the Supreme Court based its decision on private law, not judicial review. Lord Toulson said it was a, ${ }^{90}$ ... cardinal error to suppose that the public law remedies and principles associated with judicial review ... occupy the entire field whenever the party whose conduct is under challenge holds a public position.

The Supreme Court based the decision on the Marcel Principle. Given HMRC had gained information of Ingenious Media's tax affairs while undertaking its statutory tax collection function, the information was prima facie confidential. The court then examined HMRC's legislation to identify if any legislative authority authorised the disclosure. HMRC argued that education, maintaining media relations and tax fraud prevention were elements of its core tax function in its legislation. ${ }^{91}$ The Supreme Court rejected this argument and required that any such authority would have to be explicit and unambiguous to override a right of confidence a person holds. ${ }^{92}$ In this way, the Supreme Court acknowledged the blurred line between the public law proposition in Entick $v$ Carrington and private law.

\footnotetext{
${ }^{88} R$ (on application of Ingenious Media Holdings) v Her Majesty's Revenue and Customs [2016] UKSC 54.

${ }^{89}$ At 11.

${ }^{90}$ Marcel, above n 85, at [28].

${ }^{91} R$ (on application of Ingenious Media Holdings) v Her Majesty's Revenue and Customs, above n 88, at [13].

${ }^{92}$ At [19-22].
} 
The Marcel Principle has been applied in New Zealand. ${ }^{93}$ This is important because most documentary reality television focuses on public authorities as they go about their work engaging with members of the public. The access discussed earlier in this chapter is often derivative or contingent on those authority's public powers and the execution of their statutory functions. Judicial concern has already been expressed concerning access by one public authority derivative on another public authority's function. ${ }^{94}$ Media gaining access by the same means is at least no less concerning. Indeed, it could be considered more concerning, given the subsequent publication to a broader audience. American jurisprudence also suggests it is more concerning because of the risk that the media takes on the "colour of law" and leads to a misunderstanding that the media somehow has a lawful right to special access. ${ }^{95}$

Documentary reality television reverses the tradition of protection. In it involuntary participants are recorded engaging with public authorities and disclosures are made to create entertainment media. But the rise of documentary reality television in New Zealand has occurred without specific legislative authority. There has been no Police Ten 7 Act, to reverse police secrecy; and there has been no Rescue One Act, to render medical information public so long as it is entertaining. To use the example of law enforcement television, the Police are empowered by the Policing Act 2008. Section 9 of the Act contains the Police's functions and does not provide for any general publicity function. ${ }^{96}$

The functions of the Police include-

(a) keeping the peace:

(b) maintaining public safety:

(c) law enforcement:

(d) crime prevention:

(e) community support and reassurance:

(f) national security:

(g) participation in policing activities outside New Zealand:

(h) emergency management.

While there is no explicit publicity function, their functions are broad, with little context. A wide reading could allow broad disclosure of information gathered in fulfilment of policing purposes and public safety. However, section 9 should be read alongside section 95B, which permits the disclosure of personal information to a corresponding overseas agency and specifies defined limits for this power:

93 ANZ Bank New Zealand v Financial Markets Authority, above n 85; Stepping Stones Nursery Ltd v Attorney-General [2002] 3 NZLR 414; it was the basis for an unsuccessful claim in Hyndman v Walker [2019] NZHC 2188.

${ }^{94}$ Gaitau v R [2019] NZCA 32.

95 Berger $v$ Hanlon, above n 32, at 515.

${ }^{96}$ Policing Act 2008, s 9. 
(2) The disclosure of the personal information must be reasonably necessary to enable the corresponding overseas agency to perform a function in its jurisdiction that the Police perform in New Zealand under section 9.

(3) Personal information under this section may be disclosed only-

(a) in accordance with an international disclosure instrument; or

(b) in accordance with directions issued by the Commissioner under section $95 \mathrm{C}$ for the disclosure of personal information outside of an international disclosure instrument.

Therefore to give effect to section 95B, section 9 must not be given a broad reading. If public interest-based disclosure was anyway justified through section 9, then section 95 would be redundant. Furthermore, even if a broad reading is applied, this would be a similar argument to that which was dismissed in Ingenious Media, whereby standard statutory interpretation was applied to rule that ambiguous or unclear wording about public safety could not override obligations of confidence. This is because the confidence a person holds is a right of that person and statutory drafting must be unambiguous before it can override a right. ${ }^{97}$

The scope of public safety has also been tested in the English case Hellewell $v$ Chief Constable of Derbyshire. In that case the English Police attempted to justify the circulation of mugshots of a recidivist offender to local shopkeepers as a valid statutory function in order to protect public safety. Laws $\mathbf{J}$ held that the disclosure was not properly within the statutory function of the police and therefore was a breach of confidence. This was similarly argued in Brown $v$ Attorney General, however, there the police principally attempted to argue the case under the public interest defence. ${ }^{98}$

Furthermore, a narrow reading of section 9 renders the Police's role in documentary reality television unclear. While this analysis focuses on the Police (Police Ten 7, Highway Patrol), similar issues exist for Correction Officers (Dog Squad), and Immigration Officers and Customs Officers (Border Patrol). None of these agencies' enabling legislation removes a general obligation of confidence or provide a general media function. That said, this reasoning particularly affects statutory officers, because the very act of being a statutory officer, such as a Police Officer, is a prescribed statutory function. Therefore, the Marcel Principle has broad application across these officials' day-to-day work.

This is important, because an obligation of confidence not only creates equitable obligations, it also increases the basis on which an expectation of privacy can be considered reasonable. This will be significant for part two. In conclusion, even without the legal

\footnotetext{
${ }^{97} R v$ Secretary of State for the Home Office, Ex parte Simms [2000] 2 AC 115, 131.
}

${ }^{98}$ Brown v Attorney General, above n 85. 
framework of the production agreement, the relationships between the production and involuntary participants are prescribed and constrained.

\section{The Curious Situation of the Agencies' Employees}

While documentary reality television is largely arranged by the production company and the agency, it places employees of the agency in the curious position of both carrying out their jobs and being subjects of the shows. While some employees do not want to assume this role, others appear to enjoy it. Some employees have reached a level of fame from their roles on reality television. Others seem to want to use the situation to provide the best publicity for their employer. This means in executing their primary roles these employees are motivated by outcomes other than the execution of that role. This can have negative outcomes.

For example, Can't Pay We'll Take Away covers the day-to-day work of High Court Enforcement Officers in the United Kingdom. These are officers of the High Court, authorised to collect on outstanding debts. The officers featured on the show achieve a level of celebrity. In one episode of the show, as a person was evicted from their home, an Officer was captured discussing how the situation was making good television. ${ }^{99} \mathrm{He}$ also broke from his role to talk to members of the public and to take a selfie with a fan. ${ }^{100}$ Unedited footage captured him encouraging disputes between the participants and requesting the police let the dispute escalate. These motivations are discussed further in chapter six, because the exploitative or contrived situations could be considered more offensive, when they involve publication of private information.

Some New Zealand authority employees have also assumed a level of fame and (all be it temporary) celebrity. ${ }^{101}$

\section{Conclusion about the Parties and Their Relationships}

This chapter discussed how the production arrangements for documentary reality television rely on a mutually beneficial relationship between production companies and agencies. This relationship is built on an exchange of exclusive access for positive publicity. However, this symbiotic relationship runs contrary to the traditional protections that govern the relationship between people and public authorities. The access production companies

\footnotetext{
${ }^{99}$ Ali v Channel 5 [2018] EWHC 298 (Ch).

100 At [96].

${ }^{101}$ Potentially the most famous being Sergeant Guy Baldwin who famously told a suspect "[a]t three o'clock in the morning that pie has been in the warming drawer for probably about 12 hours. It'll be thermo-nuclear. You must always blow on the pie, always blow on the pie. Safer communities together, okay," The clip went viral and multiple repeats and interviews ensued.
} 
arrange is intended to create commercially successful products. The desires to produce commercially successful television and to provide publicity, can create motivations in agency employees that run against their traditional roles within those agencies. This has created examples where employees have unnecessarily escalated encounters. All of this together raises the question of whether agencies risk being joined to proceedings, the subject of the next chapter. 


\section{Could Authorising Agencies Be Liable for the Breach of Privacy?}

Having described the genre and established the parties to documentary reality television, this chapter concludes part one by considering whether agencies, such as the Police and MPI, can be considered party to the breach of privacy discussed in part two. It concludes that they can. As such, they face litigation risk for any resulting breach of privacy. ${ }^{102}$

\section{A What is Required to be Joined to a Claim}

Under the High Court Rules any party may be joined to the proceedings if that party has made a contribution towards the action subject to the claim. ${ }^{103}$ It is not necessary that a party's contribution is entirely sufficient for the claimed action or that they are exclusively responsible. And, if that party is liable, they are liable for the full remedy, not merely the contribution they made. They may then have a claim against the other contributing parties. ${ }^{104}$ Therefore, the central question for this chapter is whether authorising agencies making a contribution to the production of documentary reality television. ${ }^{105}$

\section{B The Contribution of Agencies}

An agency's contribution can be observed in three areas, when the agency: provides access; brings about the situation filmed and is active in the production. Each of these three means of contribution can occur at varying levels. For example, agencies can grant physical access to a location or can merely make that access possible through equipment or techniques (such as rescue drama). An agency could take an active role in the production by notifying the production company of a situation to be filmed, or it could use a situation already being filmed for its own purposes (such as putting out an appeal for an individual).

\section{Access}

The clearest example of the contribution of an agency is when it permits, licences, allows or otherwise makes possible the access necessary for the show. For example, as discussed in the previous chapter, MPI agrees to grant the production company access to film in MPI controlled areas for Border Patrol. The Police make available access to their police stations and police cars for Police Ten 7 and Motorway Patrol. This is access that could not be readily obtained but for specific agreement. These are locations where filming is traditionally restricted. No member of the public can freely walk into an airport Customs

\footnotetext{
${ }^{102}$ Contribution is not relevant for the BSA, where the complaint can only be against the broadcaster.

${ }^{103}$ High Court Rules 2016, r 4.3.

${ }^{104}$ Brooks v New Zealand Guardian Trust Co Ltd [1994] 2 NZLR 134 (CA). Law Reform Act 1936, s 17(1)(c).

105 Some agencies may be indemnified by the production company in the production agreement.
} 
Area, let alone film in the area. Even arrival passengers, legitimately accessing the area, are restricted from using electronic communication devices. ${ }^{106}$

Government agencies are required to comply with all the government security requirements, meaning not even all the staff of those agencies will have full access to all areas. ${ }^{107}$ Therefore, permitting access and filming in these areas is providing additional rights to production companies, beyond those of everyday people; indubitable this is contributing to the production. The counterexample would be how traditional media attend a scene and record an event from beyond the emergency tape not inside it.

Further research is required into the public law implications of the access which is being granted. It does not appear that it has ever been directly examined by the courts in New Zealand. The closest such challenge is the early privacy case of Bradley $v$ Wingnut Films. In that case the Wellington City Council permitted Wingnut Films to film in Karori Cemetery. A family whose relative was buried in the cemetery unsuccessfully sued Wingnut Films over the production. They alleged the filming breached their rights using the privacy and intentional infliction of emotional harm torts. The Bradleys did not join the Council to the proceedings, however, if they had it may have ended differently.

At that point, the Wellington City Council Parks and Recreation Department was charging for permission to film on council land. Permission to film at the Karori Cemetery was granted to Wingnut Films for $\$ 300 .{ }^{108}$ While the litigation ensued against the production company, Wellington City Council queried its own power to permit filming. The City Solicitors returned advice that Wellington City Council has "not the power or ought not to charge for filming in cemeteries". ${ }^{109}$ Despite this, the Council continued to grant permits whilst charging. Given the litigation failed, the authority of Wellington City Council to grant permissions was never resolved.

But physical access to locations is not limited to spaces that would otherwise be restricted. Another way an agency can grant access is through specialist techniques or equipment. For example, in rescue shows like Code 1, the film crew get access through the use of rescue helicopters. These helicopters allow access to areas that would otherwise be inaccessible to filming. It is a tautology that people requiring rescue are in generally inaccessible places. So too, specialist shows, like Dog Squad permit access to information not discernible by a

\footnotetext{
106 Customs and Excise Act 2018 s 216.

${ }^{107}$ Department of Prime Minister and Cabinet "Mandatory Requirements" <www.psr.govt.nz>.

108 Approval dated 15 August 1991 to Anna Cahill of Wingnut Films (Obtained under the Local Government Official Information and Meetings Act 1987 to Wellington City Council).

${ }^{109}$ Advice to David Rowe, Park Manager, from Ann Callaghan, City Solicitor, titled "Bolton Street Cemetery - Filming" dated 19 May 1992 (Obtained under the Local Government Official Information and Meetings Act 1987 to Wellington City Council).
} 
standard film crew. This equally applies to the use of x-ray machines, drug testing equipment and the use of other investigative equipment. All of these have been used for documentary reality television.

Some shows involve a mix of contribution to access, for instance in Piha Rescue the film crew gained access to club facilities and first-aid rooms, which were generally inaccessible to the public. They also gained knowledge of emergencies and specialist access through riding along on the surf rescue boats. That equipment and its use by trained staff is designed to permit access not traditionally obtainable.

\section{When the subject organisation uses its authority}

An agency can also contribute through the use of its authority or legal powers. This form of contribution usually occurs in shows where the authority is executing some public functions. For example, when the sunbathing man, discussed in chapter three, was interdicted by Maritime Police on his boat in the Marlborough Sounds he had no opportunity to leave. ${ }^{110}$ If he accelerated away as the Maritime Police arrived then he would be placed under further scrutiny and potentially accused of attempting to flee. In effect the legal powers of the Maritime Police were used to require a person to participate in a commercial entertainment television production.

An agency's power to compel access can also create access for filming. For example, in FS and Television New Zealand, an episode of The Inspectors followed Environment Health Officers carrying out a premise inspection. ${ }^{111}$ In that show, the Inspectors made negative comments about a fish and chip shop while accessing areas not typically available to the public. ${ }^{112}$ The BSA, noted that the film crew had no additional rights to enter the business than the general public and found a breach of privacy. ${ }^{113}$ The BSA made a point of noting that a film crew does not have right of entry derivative of an official's access powers. Instead, a film crews' powers are the same as any person to enter a premise. Yet these examples are not limited to this one dispute, for example, in MA and Television New Zealand, Police Ten 7 filmed the execution of a search warrant. Without those search powers provided by the search warranty, they would have no means of identifying the presence of drugs in the property. Similar is true in the American cases of Berger, Ayeni and Wilson each involved the agency using its power to create accessibility through search powers.

\footnotetext{
${ }^{110}$ PN v Television New Zealand Ltd, above n 52.

${ }^{111}$ FS And Television New Zealand Ltd BSA Decision No 2012-036, 19 December 2012.

112 The programme director commented on this access in his own note saying: "The owner knew why we were there and didn't kick us out (amazing!).” At [25]

113 At 29.
} 
These powers of compulsion are routinely exercised in airports and border areas, so filming in these areas is, in effect, compelled. Signage at the Airport directs people who do not want to be filmed to draw the attention of the film crew, however, it is difficult to see this operating when many participants do not even know they have been filmed. This is even more acute where the film broadcast is from security cameras which are placed so they cannot be avoided. The very nature of security cameras, and their use for documentary reality television, creates a significant power imbalance between the production and the involuntary participant.

Powers have also been used to capture information from people's phones and documents. ${ }^{114}$ This occurs in police shows, but more commonly, in border security shows, where border officials have broad powers to search people's luggage and possessions. While the participants have produced them, they are doing so under regulatory scrutiny that they are trying to abate. The official then returns the phone to the participant and discusses the outcome of the search, which often reveals information about the contents of the phone. Without the exercise of the agency's authority, there would be no means for the production company to gain this private material. It would not be expected that a person outside of these confines would willingly hand over their phone to be filmed or its contents discussed in this setting. ${ }^{115}$

\section{When the authority is an active producer}

Finally, agencies contribute to shows when they actively participate in the show's development. The clearest example of this is the police television show, Police Ten 7. It is hosted by agency staff and features descriptions of crimes currently being investigated, information about the suspects, and a reporting channel for tips. In another example, the Border Patrol production agreement contains the ability for MPI to alert Greenstone to matters which are of interest to proactively arrange filming. This is effectively, enshrining in a formal agreement an arrangement which is akin to Cliff Richard $v B B C .{ }^{116}$ In Cliff Richard the police faced severe criticism for tipping off the BBC about raids set to occur at Sir Cliff Richard's homes. He was successful in arguing that the disclosure was improper and obtained substantial damages and settlements from the BBC and the Police.

The miniaturization of cameras has also allowed officials to regularly wear cameras. Employees of agencies often wear these cameras for health and safety purposes. However,

\footnotetext{
${ }^{114}$ For example see, "Border Patrol" (Greenstone) series 11, episode 4.

${ }^{115}$ With the recent changes to the Customs and Excise Act 2018 Customs are now empowered to request that a person assist them by unlocking electronic devices at the border. No examples have been noted following this legislative power being introduced. See: Customs and Excise Act 2018, s 228.

116 [2018] EWHC 1837 (Ch).
} 
these same cameras have been used for recording documentary reality television. ${ }^{117}$ These cameras grant the agency a level of editorial control. When using them, the agency can control where the camera is pointing, when it is on and what it is filming. ${ }^{118}$

It is broadly accepted that cinematographers and directors in the film industry play a significant role. They can choose what the camera records and how the shot is framed. When agencies wear body cameras to take footage for reality television, they are stepping into this role. This also means that the cameras they wield are less likely to capture negative interactions which reflect badly on the agency.

Body-worn cameras also potentially have particular features that could present involuntary participants in bad light. In cinematography, close up shots are known to create more dramatic moments and increase perceptions of speed. People in close-ups appear less relaxed and are viewed less positively. ${ }^{119}$ Shooting video from a perspective that focuses directly on a suspect has also been shown to increase perceptions of guilt. ${ }^{120}$ Because bodyworn cameras are mounted on the official, close to the person they are interacting with, these negative angles are the very same shots that body-worn cameras capture. For example, if a person swings a punch at a person and that punch is recorded by a body-worn camera and by a distant film crew, it would be expected that the punch would appear much more dramatic when viewed from the perspective of the body-worn camera.

\section{Conclusion on Litigation Risk}

The test for whether a party may be joined to proceedings is whether the party made a contribution to the matter under consideration. The production agreements and the shows themselves reveal that agencies are making significant contributions towards the production of documentary reality television. Given this conclusion, agencies do face litigation risk of being joined to proceedings against a documentary reality television broadcast, as contemplated in part two.

\section{Conclusion to Part One}

The previous chapters have established the genre and the parties involved, and this chapter has established the foundation for liability of agencies involved in the production of the

\footnotetext{
117 Ali v Channel 5, above n 99.

118 This has also caused negative outcomes for officials, for example see: David Lohr "Baltimore Cop Accused of Planting Drugs in Body Cam Video Indicted" (25 January 2018) Huffpost < Huffpost.com>.

119 Sara Landström, Emma Roos Af Hjelmsäter and Pär Anders Granhag "The camera perspective bias: a case study" (2008) 4(3) Journal of Investigative Psychology and Offender Profiling 199.

120 Daniel Lassiter and others "Evidence of the camera perspective bias in authentic videotaped interrogations: Implications for emerging reform in the criminal justice system" (2011) 14(1) Legal and Criminology Psychology 157.
} 
genre. These three chapters, together, establish the basis for part two, which argues that the genre systemically breaches the privacy rights of involuntary participants. 


\section{A Framework for Breach of Privacy}

This chapter is the first of part two, which discusses how documentary reality television systemically breaches the privacy of involuntary participants. But, first, before we move to the specifics of this claim, this chapter defines what is meant by a breach of privacy and why it matters. It establishes the elements of liability which form the subsequent chapters.

\section{A The Right to Privacy}

There is a right to privacy in New Zealand. The right is protected in a variety of statutes; these include the Privacy Act 1993, the Broadcasting Standards Act 1989, the Crimes Act 1961 and the Search and Surveillance Act 2012. It is also contained in various private law protections, including the publication and intrusion torts. While it is not contained in the Bill of Rights Act 1990, many have argued that it should be, nevertheless the courts have been willing to read privacy right as a right that exists alongside the values underpinning the Act. ${ }^{121}$ This means that to be lawful, it is important that documentary reality television maintains the right to privacy. The legal right to privacy is attached to the normative right to privacy, therefore, some theoretical analysis of the right is necessary to understand the claim.

It is broadly appreciated that privacy plays a central role in an individual's ability to interact in a society, while maintaining dignity and autonomy. In the Anglo-English conception of privacy, privacy is the concept of "freedom from unwanted access"122 or "the personal 'space' in which the individual is free to be itself". ${ }^{123}$ Justice Tipping described it as "the right to have people leave you alone if you do not want some aspect of your private life to become public property". ${ }^{24}$ This definition is not synonymous with secrecy, as "modern law of privacy is not concerned solely with information or 'secrets': it is also concerned importantly with intrusion". ${ }^{125}$ Therefore, access can include access to information, sensory attention or physical proximity, even if no new informational access is achieved. ${ }^{126}$

\footnotetext{
${ }^{121}$ Petra Butler "The Case for a Right to Privacy in the New Zealand Bill of Rights Act" (2013) 11(1) New Zealand Journal of Public and International Law 213; Brooker v Police [2007] NZSC 30 at [11] per Elias CJ, at [209-230] per Thomas J (dissenting).

${ }^{122}$ As adopted in Brooker v Police [2007] NZSC 30, [2007] 3 NZLR 91 at [123] citing N A Moreham "The protection of Privacy in English Common Law: a doctrinal and theoretical analysis" (2005) 121 LQR 628 at 636. This is different to the American conception which includes an individual's autonomy and choice famously extending to the right to an abortion.

123 Prince Albert v Strange (1848) 2 De G \& SM 652, 698; 64 ER 293, 313 per Lord Mustill.

${ }^{124}$ Hosking $v$ Runting, above $\mathrm{n} 11$, at [238].

${ }^{125}$ McKennitt v Ash [2008] QB 73 at 80.

${ }^{126}$ PJS v News Group Newspapers Ltd [2016] UKSC 26.
} 
Not all access reduces privacy, only unwanted access. This is consistent with the claim that the "ordinary person wishes to exercise choice in respect of the incidence and degree of social isolation or interaction". ${ }^{127}$ Otherwise privacy would contradict human interaction. Therefore, a person sharing stories with friends cannot be said to be suffering a loss of privacy. In this way, privacy is also distinct from control, because an expression of privacy can involve the disclosure of information, losing effective control. ${ }^{128}$

\section{B The Instrumental Value of the Right to Privacy}

The protection of some expectations of privacy is involved, indeed sometimes it is a necessary state, for the development of belonging and as a safeguard against moral criticism.

Privacy plays a central role in people's ability to develop distinctive relationships. It is normal that people share more personal information with a close friend than with a general acquaintance. ${ }^{129}$ In this way, sharing personal information builds intimacy and personal information is "the moral capital which we spend in friendship and love". ${ }^{130}$ This intimacy allows groups of people to develop exclusive belonging which is instrumentally valuable. ${ }^{131}$ Edward Bloustein raises the example of a huddle in sport, without the privacy afforded to the huddle, the huddle would not function and the team could not operate at such a high level. ${ }^{132}$ These groups form important societal structures, such as Alcoholics Anonymous.

One potentially deleterious effect of a breach of privacy in reality television is removing this zone of intimacy. For example, in Andrews v Television New Zealand, Mrs Andrews did not know she was being filmed. However, if she had, one could imagine that the recording would have affected her behaviour, modifying what she thought at the time were her final moments with her critically injured husband.

\footnotetext{
${ }^{127}$ Hosking $v$ Runting, above n 11, at [264].

${ }^{128}$ Nicole Moreham "The Protection of Privacy in English Common Law: a doctrinal and theoretical analysis" (2005) 121 Law Quarterly Review 628.

129 James Rachels "Why Privacy is Important" (1975) 4(4) Philosophy and Public Affairs 323.

${ }^{130}$ C Fried, "Privacy" (1968) 77 Yale LJ 475 at 484. Eric Barendt puts this as the role of privacy in the freedom in "the development of distinctive personalities." Eric Barendt, "Privacy as a Constitutional Right and Value" at (10) in Peter Birks (ed) Privacy and Loyalty (Clarendon Press, Oxford, 1997).

${ }^{131}$ James Rachels, above n 129. Rachels discusses that without privacy society would "flatten out" and we would lose the capacity for a diversity of relationships.

${ }^{132}$ Edward Bloustein Individual and group privacy (2nd ed, Routledge, New Brunswick, 2003).
} 
Privacy also creates a zone in which people are free to access, consider and develop ideas without judgement or criticism. ${ }^{133}$ In this way privacy operates to "forestall undue accumulation of state power" and as a safeguard against moral criticism and overcriminalisation. ${ }^{134}$ A common comment about privacy is ' $I$ have nothing to hide', but it is impossible to know what information, true or false, could result in criticism. As pointed out by James Duane, even if a perfectly pure person did exist, it would be impossible for that person to know whether some fact, mistaken or not, could create a perception of guilt. $^{135}$

Documentary reality television contrasts this instrumental value by creating accessibility to people's lives, often for the purpose of criticism. Many shows' public purposes are crafted making examples of people doing the wrong thing, such as getting stuck in rips, drink driving and being suspected of wrongdoing. However, the criticism is occurring outside of the strictures of a judicial process, without the rights of an accused and often without any right of reply. People are publicly paraded to an international audience for what are often minor transgressions.

Recording people dealing with public authorities could also modify their behaviour engaging with those authorities; leading them to be less honest and complete in their answers to avoid humiliating coverage. This modification of behaviour risks undermining the primary purpose of the agency's interaction with the individual. For example, if someone is receiving first aid, they are less likely to admit to taking drugs while being recorded, which is a beneficial disclosure for the purpose of providing first aid. This risks the very purpose the shows are aiming to promote and the safety of individuals within rescue or medical situations. ${ }^{136}$

But privacy is not only of instrumental value, it is also of moral importance. Privacy is morally justified because of its role maintaining the dignity and autonomy of individuals.

133 Stanley Benn 'Privacy, Freedom and respect for persons' in Pennock and Chapman (eds) Privacy (NOMOS vol XIII, Atherton Press, New York, 1971) 1.

${ }^{134}$ At 129.

135 James Duane, You have the right to remain innocent (Little A, Seattle, 2016).

136 For example, in the episode of Bondi Rescue where the topless teenager refused to get on the rescue equipment due to the presence of the camera, see footnote 2 . 


\section{Privacy Plays a Central Role in Dignity, Autonomy and Wellbeing.}

This moral value of privacy has significant judicial support. In Campbell v MGN privacy is considered to be "something worth protecting as an aspect of human autonomy and dignity". ${ }^{137}$ In Hosking $v$ Runting, Tipping J said, ${ }^{138}$

It is of the essence of the dignity and personal autonomy and well-being of all human beings that some aspects of their lives should be able to remain private if they so wish.

These comments centre on protecting people from becoming a "public spectacle". ${ }^{139}$ This is best displayed by Gulativ MGN Ltd. Gulati concerned English tabloid writers hacking into people's private voicemail messages for stories. ${ }^{140}$ The victims developed a deep sense of distrust, fear of paranoia, and started socially isolating themselves from friends and family. ${ }^{141}$ The damages in Gulati reflect the hurt feelings and distress, but also the fact that plaintiff's lives were reduced to mere spectacles. ${ }^{142}$

Furthermore, the plaintiffs in Gulati were treated as a means rather than ends. In this way, the action was not merely a vindicatory action, but was a broader action for the loss of human autonomy. ${ }^{143}$ Parallels can be drawn between hacking a person's phone and recording a person's intimate conversations without their knowledge at a crash sceneboth involve accessing someone's information without their consent or awareness. In this way, documentary reality television commodifies people's experiences. Their stories are not used on their own terms, but are simply the canvas on which the agency tells its own story.

The commodification of people's experiences is adversely linked with the protection of their wellbeing. ${ }^{144}$ People under close media coverage talk of feeling victimised; distressed; and a strong sense of loss. Professors Nicole Moreham and Yvette Tinsley studied the outcomes of intense media interest following the Pike River Mining Disaster. They found that the subjects nearly universally reported the presence of journalists to have been

137 [2004] UKHL 22 at [50] per Lord Hoffman.

138 Above n 11, at [239].

${ }^{139}$ Edward J Bloustein "Privacy as an aspect of human dignity: an answer to Dean Prosser" in Ferdinand D Schoeman (ed) Philosophical Dimensions of Privacy: An Anthology (Cambridge University Press, United Kingdom, 1984) 156 at 170.

140 Gulati v MGN [2015] EWHC 1482 (Ch).

${ }^{141}$ At [275], [298], [406], [461], [485-488] and [570].

${ }^{142}$ At [111].

${ }^{143}$ Gulati v MGN Ltd and others [2015] EWCA Civ 1291 at 48 per Arden LJ, cited in Henderson v Walker [2019] NZHC 2184 at [209].

${ }^{144}$ See Hosking $v$ Runting, above n 11, at [239] per Tipping J. 
"oppressive". People reported feeling 'used' and 'hounded'. ${ }^{145}$ In multiple places people reported modifying their behaviour and expression. ${ }^{146}$

Importantly, this underpinning of privacy in dignity, autonomy and wellbeing extends beyond academic curiosity to play a functional role in judicial reasoning. In Henderson $v$ Walker Thomas $\mathrm{J}$ cites the normative basis for the tort as a functional element that should be considered in the disposition of a case. ${ }^{147}$ This means when applying the right to privacy, we must consider the right's foundation in dignity, autonomy and wellbeing. Practically applying the framework for a breach of privacy is made easier by the courts and the BSA applying three core elements in common for establishing a breach of privacy through the publication of private material.

\section{The Framework for Breach of Privacy by Publication}

The three core elements required to establish a breach of privacy in the BSA and the publication of private material torts are that:

1. The material must be subject to a reasonable expectation of privacy. ${ }^{148}$

2. The publication of this material must be highly offensive to a reasonable person in the place of the individual. ${ }^{149}$

3. Nevertheless, a claim will fail if there is a defence, including public concern. ${ }^{150}$

\section{E The First Element is the Reasonable Expectation of Privacy}

It is broadly accepted that not all access to a person is wrong. For that reason, there is a need to constrain what access is considered private. That constraint needs to reflect that some access is acceptable, even when it is undesired. A person who walks down the street may not 'desire' to be seen, but accepts that such access is a reasonable trade-off for public travel. Some interactions are even so societally valuable that they should be permitted to occur even against a person's wishes. ${ }^{151}$ For example, given their choice, a thief would rather have absolute seclusion from the police, but that access is considered societally desirable, even it is subjectively undesirable for the thief. Finally, the constraint needs to recognise that some people have subjective appreciations of privacy very different to

\footnotetext{
${ }^{145}$ Nicole Moreham and Yvette Tinsley "Grief Journalism, Physical Intrusion, and Loss: The Pike River Coal Mine Disaster" in Andrew T Kenyon (ed) Comparative Defamation and Privacy Law (Cambridge University Press, 2016) 115.

146 At 132-135.

${ }^{147}$ Henderson $v$ Walker, above $\mathrm{n} 12$ at [213] [58-68] and [212].

${ }^{148}$ Hosking v Runting, above n 11, at [117], Broadcast Standards Authority Broadcasting Standards in New Zealand Codebook (Broadcasting Standards Authority, Wellington, 2016) at standard 10c.

149 At standard 10b.

150 At standard 10f.

${ }^{151}$ Hosking $v$ Runting, above n 11, at [129]-[135].
} 
others. Indeed, some people have such a particular sensitivity to the disclosure of their personal information that society does not recognise it, so the law does not protect all subjective desires.

The need to constrain expectations of privacy is met by the reasonable expectation of privacy test. This test allows the normative (subjective) claim to privacy to enter the legal domain and restricts claims of overly sensitive or malicious nature. This means that a legal claim against a friend who says "Jill, meet Bob", disclosing a person's name in an introduction, will be unsuccessful. Both before the courts and the BSA, a claim will not succeed unless an individual has a reasonable expectation of privacy in the material. Two particular complexities with this standard are the role of consent and the need for the identification of the complainant. ${ }^{152}$ These matters are dealt with later in chapter seven, however, generally one does not have a reasonable expectation of privacy vis-à-vis a disclosure they consent to or in which they are not identified. ${ }^{153}$

\section{F The Second Element is Highly Offensive Publication}

Even limited by the reasonable expectation of privacy test, there is remaining concern that not all publication of private material should be actionable. For this reason, both the BSA and the tort require that the publication of the material is highly offensive to an objective reasonable person.

As will be dealt with in chapter six, the intention of the highly offensive test is to reduce the number of unmeritorious claims brought against publishers of personal information. This was considered required because "it is quite unrealistic to contemplate legal liability for all publications of all private information". ${ }^{154}$ Instead the intention is to limit the claim to those publications which are "truly humiliating and distressful or otherwise harmful to the individual concerned". ${ }^{155}$ However, this does not extend to the level of requiring economic loss. ${ }^{156}$

\footnotetext{
152 Broadcast Standards Authority Broadcasting Standards in New Zealand Codebook (Broadcasting Standards Authority, Wellington, 2016) at standard 10g and 10a.

153 One point of difference between private law and the BSA is regarding the need for an individual to be identified. The BSA expressly requires that material must identify the individual in order to breach the standard. The courts have been comparatively welcoming to claims where the plaintiff cannot be identified. See $L v G$ [2002] DCR 234. Yet still, in most instances the courts will require a level of identification. Andrews $v$ Television New Zealand, above n 62, at 52

${ }^{154}$ Hosking $v$ Runting, above n 11, at [125].

155 At [126].

156 At [127].
} 


\section{G The Third Element is the Absence of a Defence}

The final pillar is the absence of a defence to the publication. The most frequent defence being that the broadcast was in the public concern. This inquiry into the public concern in disclosure is not limited to wrongdoing by the claimant and can include broader interests such as public safety. ${ }^{157}$ The need to allow some publication based on public concern is justified by the considerable weight placed on freedom of expression and because, like other rights, the right to privacy is not absolute. Instead, it exists within an intersection of other values and rights in society.

Freedom of expression is a fundamental right of considerable weight. It is contained in section 14 of the Bill of Rights 1990 and numerous international agreements. As famously stated by Lord Steyn in $R v$ Secretary of State for the Home Department Ex Parte Simms, ${ }^{158}$

Freedom of expression is, of course, intrinsically important: it is valued for its own sake. But it is well recognised that it is also instrumentally important. It serves a number of broad objectives. First, it promotes the self fulfilment of individuals in society. Secondly, in the famous words of Mr. Justice Holmes (echoing John Stuart Mill), "the best test of truth is the power of the thought to get itself accepted in the competition of the market." Thirdly, freedom of speech is the lifeblood of democracy. The free flow of information and ideas informs political debate. It is a safety valve: people are more ready to accept decisions that go against them if they can in principle seek to influence them. It acts as a brake on the abuse of power by public officials. It facilitates the exposure of errors in the governance and administration of justice of the country.

However, whilst balancing freedom of expression it is important to consider that some material is valuable precisely because it is undisclosed. ${ }^{159}$ For instance, a credit card number or a password is useful precisely because of its exclusivity. This view is not only academic or intuitive, for instance in Von Hannover (No 1) the court acknowledged that persistent photography reduced the scope of personal relationships that the plaintiff could develop and express. ${ }^{160}$ In this way, privacy can enhance freedom of expression.

Freedom of expression is also required for a functioning media. As stated by Lord Bingham, "it is only a small minority of citizens who can participate directly in the discussions and decisions which shape the public life of that society", and it is through the media that the majority are "alerted and informed about matters which call or may call for consideration and action". ${ }^{161}$ Therefore, he concludes, "[t]he proper functioning of a modern participatory democracy requires that the media be free, active, professional and

\footnotetext{
${ }^{157}$ Andrews v TVNZ, above n 62, at [86].

158 [2000] 2 AC 115 at 131 (HL).

159 Ruth Gavinson "Privacy and the Limits of Law (1980) 89 Yale Law Journal 421.

${ }^{160}$ Von Hannover (No 1) [2004] EMLR 379.

${ }^{161}$ McCartan Turkington Breen v Times Newspapers [2000] UKHL 57 at [1].
} 
enquiring". ${ }^{162}$ The extent to which this argument applies is contentious. For example, much media focuses on the lives of celebrities and matters of little democratic importance.

The role of freedom of expression protecting media freedom can be expressed either as weak (direct) or strong (indirect) public value. The direct approach sees a free media as a means for providing journalistic coverage of civic processes. A broader approach considers freedom of expression through a requirement for a strong media which is commercially viable. This approach sees the media as a "pillar of democracy" which needs to be firmly supported to act within a margin of appreciation beyond civic reporting. ${ }^{163}$ The Leveson Enquiry also found that the strong approach means news services are more incentivised to pursue commercial success than civil goods. ${ }^{164}$ However, it is clear that there is some indirect benefit. For instance, the history of protest expression does not only include studious essays, but also popular culture, rock music, country music and graffiti.

The different approaches can be observed in the practical applications of the public concern defence. For example, in the English cases $A v B$ and Campbell $v M G N$ contrasting approaches are taken. In $A v B$, Lord Woolf CJ found that a broad level of freedom is required, to support a strong media, so public interest should cover matters where the public has a legitimate interest. ${ }^{165}$ Comparatively Campbell $v$ MGN held that a direct public interest is required. This will be discussed further in chapter seven, in particular with reference to the argument that documentary reality television is justified by public safety purposes.

\section{H Conclusion on the Framework for Breach of Privacy}

This chapter has demonstrated that there is an actionable right to privacy consistently applied based on the three elements of a breach of privacy. They are that a broadcast that publishes information subject to a reasonable expectation of privacy, in a way that is highly offensive, is a breach of privacy absent a defence. When the three elements are met, they establish that a broadcast is a breach of privacy. The following chapters consider each of these elements in turn.

\footnotetext{
${ }^{162}$ McCartan Turkington Breen v Times Newspapers, above n 161, at [1].

${ }^{163}$ Weller v Associated Newspapers Ltd [2014] EWHC 1163 (QB) at [77].

${ }^{164}$ Lord Justice Leveson An inquiry into the culture, practice and ethics of the press (Leverson Inquiry, November 2012) at 4.11.

${ }^{165} A v B$ (2002) EWCA Civ 337 at xii per Lord Woolf CJ.
} 


\section{The Genre Broadcasts Private Material}

This chapter discusses how documentary reality television frequently engages with material which traditionally would be considered subject to reasonable expectations of privacy. This argument cannot be wholly divorced from the prior chapter on the traditional protection of material gathered in the furtherance of public functions, however it is broader. It is broader because it applies to material published, not merely to the point of collection. First, however, it is worthwhile returning to what is meant by the claim that material is subject to a reasonable expectation of privacy.

\section{A What is Meant by “a Reasonable Expectation of Privacy”?}

In Hosking $v$ Runting, the leading judgment of Gault $\mathrm{P}$ and Blanchard $\mathrm{J}$ stated that the fundamental requirement for a privacy claim was "the existence of facts in respect of which there is a reasonable expectation of privacy". ${ }^{166}$ Tipping $\mathrm{J}$ broadly accepted this requirement, however, he also expanded the scope of the test to include claims "in respect of the information or material which the defendant has published or wishes to publish". ${ }^{167}$

This divergence leaves two conceptions of the reasonable expectation of privacy test, a narrow test, focused on facts, and a broad test, focused on facts or material. Professor Nicole Moreham has criticised the narrow test for missing the underlying nature of a privacy claim. ${ }^{168}$ She notes that privacy concerns more than mere facts, but extends to all aspects of accessibility to individuals. ${ }^{169}$

The divergence was considered by Justice Allan, in Andrews v Television New Zealand, who preferred the broader definition. ${ }^{170}$ The Supreme Court in Rogers $v$ Television New Zealand also acknowledged that a claim could exist over video material, even if the facts contained in that broadcast were public knowledge. ${ }^{171}$ The Supreme Court, therefore, applied the broader test. For these reasons, the correct application of the reasonable expectation test extends to the full range of facts and material, consistent with Tipping J's approach in Hosking $v$ Runting.

The existence of private facts cannot be separated from the reasonable expectation of privacy. That is to say, the test is unitary, and not about whether there are private facts distinctly considered from whether there is a reasonable expectation over them. This means

\footnotetext{
${ }^{166}$ Hosking $v$ Runting, above $\mathrm{n} 11$, at [117] per Gault $\mathrm{P}$ and Blanchard J.

167 At [249] per Tipping J (emphasis added).

168 N A Moreham, above n 122.

169 At 648-656.

170 Above n 62, at [26].

171 [2007] NZSC 9 at [103].
} 
that the test is contextual and does not stop because the information does not involve "inherently private matters". ${ }^{172}$ Indeed, private facts "[m]ay be known to some people"; they just cannot be known "to the world at large". ${ }^{173}$ This also means that information that was once public can regain a sense of privacy over time. ${ }^{174}$

For tortious publication usually the contested material must identify the plaintiff. ${ }^{175}$ However, material which does not identify an individual may be subject to a reasonable expectation of privacy. ${ }^{176}$ This aligns with the idea that privacy is not about information, but is about access to people. ${ }^{177}$ This differs from the Broadcasting Standards which require that the broadcast identifies the individual to people other than the individual's close friends and family. ${ }^{178}$

This contextual nature of the test means, ultimately, that the disposition of an individual case will require a contextual inquiry into all of the relevant facts, not a generic analysis of a genre at large. However, by looking at past applications of the test, a thematic approach is possible. This can be done by considering traditional societal protection of information and the signals people display which reveal a desire for inaccessibility. ${ }^{179}$ The first is achieved by looking at matters which society traditionally deems worthy of protection. These are usually matters which are close to a person's biographic core, such as sexual, financial, biographical, and other such personal matters. People can also signal expectations of privacy through explicit actions and implicit behaviour. ${ }^{180}$ For example, the barriers people use to create inaccessibility also signal expectations of privacy; these can be normative, behavioural or societal barriers. ${ }^{181}$

It is important to note, however, that not all information which is protected is private. Indeed, there are some forms of information society deems worthy of protection or inaccessibility, which are not private information. ${ }^{182}$ For example, a person could contract for information to be inaccessible - while that may be an indicator of an expectation of

\footnotetext{
${ }^{172}$ Rogers $v$ Television New Zealand [2007] 1 NZLR 156 (CA) at [59].

${ }^{173}$ At [119] per Gault P and Blanchard J.

${ }^{174}$ At [54] per O'Regan and Panckhurst JJ and per WilliamYoung P at [123].

${ }^{175}$ Andrews $v$ TVNZ, above n 62, at [52].

${ }^{176} L v G$, above n 153.

177 At [246].

178 Broadcasting Standards Authority, above n 152, standard 10a.

179 This approach is based on Nicole Moreham, "Unpacking the reasonable expectation of privacy test"" above n 12 .

180 At 7-9.

${ }^{181}$ Kirsty Hughes “A Behavioural Understanding of Privacy and Its Implications for Privacy Law” (2012) 75(5) Modern Law Review 806.

182 This is why it is necessary to discuss reasonable expectations of privacy even though chapter three has already established that much of the material involved in documentary reality television is confidential.
} 
privacy, it does not, itself, generate a privacy interest. The broader implication of this conclusion is that one cannot judge whether a particular material is private solely by considering whether it bears a character of being restricted. Only the information protected for those reasons linked to the normative privacy claim can be considered private. In considering this, relevant factors include: ${ }^{183}$
a) the attributes of the claimant;
b) the nature of the activity in which the claimant was engaged;
c) the place at which it was happening;
d) the nature and purpose of the intrusion;
e) the absence of consent and whether it was known or could be inferred;
f) the effect on the claimant; and
g) the circumstances in which and the purposes for which the information came into the hands of the publisher.

This means it is relevant, but not determinative, whether there is an obligation of confidentiality covering the material. ${ }^{184}$ This inquiry is then completed by considering whether the material is consistent with that which is protected by privacy - the dignity, wellbeing and autonomy of individuals. ${ }^{185}$

\section{B The New Access Focuses on Traditionally Protected Spatial Areas}

Documentary reality television often focuses on spatial areas which are subject to traditional societal protections. In particular, these include locations such as homes, controlled areas, bags and correspondence. Subject matters which are considered private are also included, such as medical, sexual and financial information.

\section{Access to Spatial Areas Traditionally Protected}

Some spatial areas which are traditionally considered subject to privacy protections are homes, cars, correspondence and bags. These spatial areas are marked by significant histories of protection and physical barriers creating inaccessibility. Productions frequently access these spatial areas for documentary reality television.

\section{Access to homes}

Traditionally, within homes, "even relatively trivial details" are covered by privacy expectations "because of the traditional security accorded to hearth and home". ${ }^{186}$ Yet, in

${ }^{183}$ ZXC v Bloomberg [2009] EWC 970 (QB) citing Murray v Express Newspapers [2008] EWCA Civ 446 (Ch) at [36] and re JR38 [2015] UKSC 42 at [60].

${ }^{184}$ ZXC v Bloomberg, above n 183, at [125].

${ }^{185}$ Henderson $v$ Walker, above n 12, at [202].

${ }^{186}$ Ash v McKennitt [2006] EWCA 1714 (Civ) at [21] per Buxton LJ. 
defence of a complaint against filming a search warrant, Television New Zealand argued that Police Ten 7 "had filmed hundreds of search warrants" and that "[t]hey are well qualified to gauge people's reactions to having a camera crew on their property in these situations". ${ }^{187}$ Shows frequently access people's homes and film from the sidewalk into private property. Importantly, the significant protection of matters pertaining to the home is not limited to the information contained secret within one's home. It extends to matters visible from public areas, and even the location of a home can itself be subject to protection. $^{188}$

\section{Access to cars}

There is also a well-established expectation of privacy covering the contents of cars. However despite that expectation, shows like Dog Squad and Police Ten 7 frequently film searches of vehicles. ${ }^{189}$ In these searches officers inspect the contents of cars and use dogs to find concealments. The use of sniffer dogs further breaks traditional barriers around access people would expect to their vehicles. Furthermore, rarely are viewers told of the occurrence of false positive indications, leaving an implication of guilt even if no physical evidence is found.

\section{Bags and packages}

Border protection shows such as Border Patrol, Customs and Border Force frequently film searches of luggage, packages and handbags. Where personal bags are sealed and opaque they are subject to barriers that make them inaccessible, meaning they hold heightened expectations of privacy. ${ }^{190}$ In Caine Kereama Kahotea $v R$ the Court of Appeal considered a search of a bag constituted an unreasonable search, meaning it bore a reasonable expectation of privacy. ${ }^{191}$ In the first-instance judgment, the District Court said, "the privacy right attaching to a bag in a car was not as important as that attaching to a dwelling, mobile phone or computer...". ${ }^{192}$ So, while the privacy expectation afforded to bags may be less than homes or mobile devices, the access to them is traditionally protected.

This means that the expectation of privacy over bags will be stronger at airports, where bags are usually robust and locked, and less justified if an item protrudes, or is visible

\footnotetext{
${ }^{187} M A v T V N Z$, above $\mathrm{n} 1$.

${ }^{188}$ For example, the location of the claimant's home was included in the material injuncted from publication in Venables $v$ News Group News Papers [2001] EWHC 32 (QC).

${ }^{189} R v$ Williams [2007] NZCA 52 at [113].

190 William Fussey "Determining Reasonable Expectations of Privacy in the Intrusion into Seclusion Tort" (2016) 22 Canterbury Law Review 269 at 279.

191 [2017] NZCA 82.

${ }^{192} R$ v Kahotea [2016] NZDC 24926 at [28-34].
} 
through the bag. ${ }^{193}$ This is relevant for border protection shows, where often the illegal smuggling of cigarettes is detected by the unusually boxy shape of the bag. Based on the analysis above, these instances will attract a lower expectation of privacy than, for example, the contents of bags discovered during a random search.

\section{Documents and correspondence}

There is also a deep history of the protection of diaries, documents and correspondence. ${ }^{194}$ In numerous examples border protection shows have broadcast the contents of documentation and correspondence, either through directly broadcasting them or through discussing the contents. Most frequently this material is broadcast as part of an assessment of a traveller's bona fide eligibility to enter a country. This access contravenes traditional access protections of these items and interactions, which is an indicator that people in these situations would likely have expectations of privacy. No general member of the public may require another person to reveal the contents of their papers or correspondence, yet prima facie the media has no greater right to obtain this access. ${ }^{195}$

Production crews also gain privileged access to typically restricted areas through the production agreements. Aside from for security reasons, filming is not traditionally permitted in border control areas or police stations, so a person in these areas would not reasonably expect to be recorded for entertainment television. Indeed, the very fact that the parties to the production agreement consider it necessary to agree to access provisions, demonstrates that filming in these areas is traditionally limited, or, at the very least, that the agency may limit access. Moreover, if the agency did not have the ability to limit access, anti-competition clauses as observed in production agreements would be eroded.

\section{Is the Filming Occurring in Public Places?}

While some filming occurs in traditionally protected locations, it is also often stated that documentary reality television shows are filmed in areas with public accessibility. As such, producers claim they are filmed in public places and that there is no reasonable expectation of privacy. ${ }^{196}$

\footnotetext{
${ }^{193}$ For example in Shaun Michael Moore $v$ R [2017] NZCA 577 a combat knife protruded from a person's bag, no argument was made that fact the knife in the bag was private.

${ }^{194}$ Hence correspondence's place in the United Nations Declaration of Human Rights 1948, Article 12 "No one shall be subject to arbitrary interference with his privacy, family, home or correspondence." See also Entick v Carrington, above n 13, and in particular the concern raised about the contents of the correspondence seized and how much it could reveal about Mr Entick.

195 FS And Television New Zealand Ltd, above n 111.

196 Indeed, it is pre-emptively stated on Greenstone TV's website, see "Will I be on TV?" < http://www.greenstonetv.com/will-i-be-on-tv/>.
} 
Historically, there is some support for the proposition that events that occur in public places are not private. For example, in Hosking $v$ Runting the joint judgment of Gault $\mathrm{P}$ and Blanchard J cited but ultimately dismissed a passage from Dean Prosser's influential Restatement of Torts saying, ${ }^{197}$

The decisions indicate that anything visible in a public place may be recorded and given circulation by means of a photograph, to the same extent as by a written description, since this amounts to nothing more than giving publicity to what is already public...

They also cite Re McAllister, in which they describe the BSA as saying, ${ }^{198}$

...on a public street or in any other public place, the plaintiff has no legal right to be let alone, and it is no invasion of privacy to follow him about and watch him there, nor to take a photograph of him.

They ultimately found that reasonable expectations of privacy could exist in public places; but the particular facts did not amount to a breach of privacy. This was because the photograph did not reveal anything more than could have been observed by any member of the public in Newmarket on that day. ${ }^{199}$

While the majority acknowledged that expectations of privacy can exist in public places, the threshold still appears too high when considered in light of the framework provided in chapter five. If the key question concerns the reasonable expectation of privacy that a person holds against particular access, then the fact that the material was emanated to the people of Newmarket is distinguishable from the intentional publication to the world at large.

While anyone in Newmarket may have achieved the same accessibility as a viewer of a photo, the entire readership of New Idea! was not in Newmarket, on that street, on that day. Furthermore, the actual content published was materially different to the information obtainable to people on the street. The general population of Newmarket would have seen two children, but would not necessarily have known that those children were $\mathrm{Mr}$ Hosking's children or the additional context of the story. In this respect New Idea! added context and enabled additional accessibility. Finally, a captured image allows people to examine and return to information far more than is possible within standard public settings.

Since Hosking $v$ Runting, in Hamed $v R$ Elias CJ accepted that a reasonable expectation could exist in a public place if they a person reasonably believed themselves to be "out of sight or earshot". ${ }^{200}$ In a similar fact pattern to Hosking $v$ Runting the English Courts of

\footnotetext{
${ }^{197}$ Dean William L Prosser "Privacy” (1960) 48 Calif L Rev 383, 409 at 394 cited in Hosking v Runting, above $\mathrm{n} 11$, at [71].

198 At [86] citing Re McAllister [1990] NZAR 324.

${ }^{199}$ Hosking $v$ Runting, above $\mathrm{n} 11$, at [164].

200 [2011] NZSC 101 at [320] per Elias CJ (dissenting).
} 
Appeal accepted that a reasonable expectation did exist in Murray $v$ Express News Papers. $^{201}$ The European Court also accepted that a person had a reasonable expectation of privacy following a suicide attempt, even though he was in a public area. ${ }^{202}$ These judgments all focus on the subjective expectation of solitude, meaning the standard reasonable expectation of privacy test is applied. For example, a person in a crowd may expect to be overheard by a bystander, but they would not expect to be recorded by a telescopic microphone or a listening device. ${ }^{203}$

This means that public places should not be considered exempt from expectations of privacy, instead their public domain should be considered as another part of the contextual reasonable expectation of privacy test. This contextual investigation should include the location of the activity, the activity of the claimant, and the way in which the recording was obtained. ${ }^{204}$

In any instance, most documentary reality television is not recorded in putatively public places. The places where filming occurs are often are restricted areas or places without general accessibility. Locations such as airports, hospitals and police stations are subject to visitation and filming restrictions. In other locations, dangerous features or remote locations restrict general access.

In recent times, civil advocacy groups have encouraged people to record interactions with law enforcement. These groups include Black Lives Matter and the concept of First Amendment Audits. ${ }^{205}$ Fairly universally, when people try they are requested by public authorities to stop filming. Indeed, just recently, Hawkes Bay District Health Board went to significant lengths (including calling the Police) to remove one of New Zealand's most senior investigative journalists from reporting from a hospital. ${ }^{206}$ A Northland police officer was reprimanded for threatening to ticket a person for recording him interacting with a teenage driver. ${ }^{207}$ These examples demonstrate public authorities believing that they have the power to restrict filming of interactions with them or in their premises, which contradicts that these areas are marked by unfettered access to film.

\footnotetext{
${ }^{201}$ Murray v Express News Papers, above n 183.

${ }^{202}$ Peck $v$ the United Kingdom [2003] EHRR 287.

203 A comparator can be drawn that there is no exception to criminal covert recording that the recording occurred in public. See: Crimes Act s 216.

${ }^{204}$ N A Moreham "Privacy in Public Places" (2006) 65(3) CLJ 606.

${ }^{205}$ In both instances this is intended to record any negative engagements with authority.

${ }^{206}$ Melanie Reid "New Zealand's own taken generation" (11 June 2019) Newsroom.co.nz $<$ https://www.newsroom.co.nz >.

207 "Police Apologise after offer threatens to ticket filming teenage" 20 January 2019 <https://www.stuff.co.nz >.
} 
In other shows, physical barriers restrict unfettered accessibility to otherwise public places. For example, surf rescue equipment is designed to gain access to difficult to reach areas. When that equipment is used to access an area, it should not be considered equivalent to a traditionally public zone. Similar access is obtained by rescue helicopters and long-range photography. In these ways, the zones accessed in rescue television are often not consistent with standard public places.

Even when access is to a purely public place, the level of access is still inconsistent with the access traditionally expected in day-to-day affairs. Documentary reality television's use of search dogs, one-way mirrors, x-ray machines, long-range lenses, closed-circuit television (CCTV), and high-tech microphones all allow for additional access to what is usually available. ${ }^{208}$ For example, in one episode of Border Patrol a person is intercepted following unusual behaviour observed on security cameras. ${ }^{209}$ The show broadcasts CCTV footage of him passing through the common area of the airport, the declaration gate and from within the interview area. The show broadcasts one shot from directly above the search table, looking down on his possessions from a security camera it would be unlikely anyone would normally see. It is worth drawing a comparison to Perry $v$ United Kingdom where cameras in a police station were repurposed to gain identification pictures. ${ }^{210}$ The European Court of Human Rights found that "[t]his ploy adopted by the police went beyond the normal or expected use of this type of camera" and the Police's actions constituted a breach of privacy. ${ }^{211}$ No one would standardly expect that footage from security cameras in an airport would be repurposed for entertainment television. Additionally, these technologies all reduce the capacity of an involuntary subject to retreat from access; for good reason, no one has the capacity to avoid security cameras within an airport.

Where covert or long-range filming is used it should be considered equivalent to a hidden camera. The Broadcasting Standards Codebook says that hidden cameras will usually be considered intrusive. ${ }^{212}$ Such intrusion can only be justified by significant newsworthiness. For example, in TV3 Network Services $v$ Fahey the court found surreptitious filming was justified by the significant news value in the recorded content. ${ }^{213}$ The BSA has however made clear that hidden cameras are not justified in all instances where something is of news value, the news value must be so significant as to overwhelm the intrusion. ${ }^{214}$

\footnotetext{
${ }^{208}$ In one episode of Coastwatch the film crew even uses camouflage and a hide away to disguise recording (and law enforcement activity) during a sting on overfishing.

${ }^{209}$ Series 7, episode 2.

210 [2003] ECHR 375.

211 At [41].

212 Broadcast Standards Authority, above n 152, standard 9.3.

${ }^{213}$ TV3 Network Services v Fahey [1999] 2 NZLR 129.

${ }^{214}$ De Hart v TV3 Network Services Ltd BSA decision No 2000-108-113 (10 August 2000).
} 
Moreover, the prolonged and intensive attention of film crews is itself a form of atypical access. For example, in Andrews $v$ Television New Zealand, Alan J pointed to the close observation for over an hour as going well beyond standard access permissible in public places. $^{215}$ The Andrews could not leave this filming because they were injured and $\mathrm{Mr}$ Andrews was trapped in the vehicle.

For these reasons, documentary reality television often films in locations which are typically subject to protection. It also includes topics which are usually considered private.

\section{E The Genre Involves Topics Usually Considered Private}

It is broadly accepted that some topics are considered putatively private. These are usually topics which involve matters close to our biographic core. ${ }^{216}$ Nicole Moreham suggests that there are seven categories, which include information relating to: ${ }^{217}$

(i) the appearance or workings of the physical body (including matters relating to health, bodily functions, and nakedness);

(ii) to sexual encounters or activity;

(iii) to the intimate details of one's personal relationships;

(iv) to the intimacies of one's family and/or domestic life;

(v) to the experience of trauma, grief or strong emotion;

(vi) to the inner workings of one's mind (including strong emotion and the content of fears, fantasies, dreams); and

(vii) to detailed patterns of one's daily life (as would be observed, for example, as a result of systematic surveillance).

Documentary reality television frequently includes these topics. Most frequently this is in law enforcement, rescue and medical shows. For example, when a person is asked about:

- their health status in order to determine whether they are eligible to enter the country;

- the source of money in their possession; or

- their medication while being provided first aid.

However, there are also numerous examples within other formats. For example, border shows frequently focus on the unusual and embarrassing contents of people's luggage. The most noteworthy of these examples is where sex paraphernalia is found in people's luggage and becomes the focus of dedicated coverage.

But what makes this breach systematic is that this same access which is what provides the public's interest in the genre. Imagine an episode of Piha Rescue where a person is spotted at sea, they are returned to shore and provided first aid. The camera films from a distance

\footnotetext{
${ }^{215}$ Andrews v Television New Zealand, above n 62, at [64].

${ }^{216}$ N A Moreham, above $n 179$.

${ }^{217}$ At 6 (line breaks added).
} 
not recording particular context or conversations. Such a show would doubtlessly perform less well than the actual show- because, as discussed in chapter two, it is the human story that motivates the viewers.

One class of information involved in documentary reality television is particularly difficult; that is potentially prejudicial law enforcement information. Not only is it difficult, its disposition is highly relevant because of how much law enforcement information is included in documentary reality television. Any conclusion that law enforcement information is highly sensitive would drastically curtail the genre.

\section{F The Difficult Situation of Law Enforcement Information}

Potentially prejudicial law enforcement information is the most unclear category of material because it is the least settled category of information and also the most polarized. It is polarizing because there is significant judicial support for the proposition that law enforcement information is subject to significant expectations of privacy and for the proposition that it is not at all. Which side of this dichotomy material falls on is case specific, but there are some general propositions that can be found.

1 Proposition one: there is no general presumption of innocent guaranteeing privacy protections of all prejudicial information

The first proposition is that people do not have a general right to be presumed (or thought) innocent. ${ }^{218}$ The presumption of innocence is a safeguard maintained in the criminal jurisdiction to protect people from wrongful conviction. ${ }^{219}$ It is not a general societal rule that everyone must treat everyone not convicted of a crime as innocent. In Driver $v$ Radio New Zealand, Clark J affirmed that "[it] does not imply an accused is factually innocent or must be treated as such by the public". ${ }^{220}$ In doing so Clark J incorporates the English Supreme Court case of Khuja $v$ Times Newspapers. ${ }^{221}$

In Khuja $v$ Times Newspapers an individual had been subject to prosecution for serious sexual offending. While the case proceeded Mr Khuja was afforded name suppression. However, charges were dropped, meaning he was no longer entitled to suppression of his name. He applied for a privacy injunction but he failed based on the lack of a reasonable expectation of privacy. In the majority judgment delivered by the court, Lord Sumption found that there was an "impact which publication would have on [Mr Khuja's] relations

\footnotetext{
${ }^{218}$ Driver v Radio New Zealand Limited [2019] NZHC 3275 at [108-109].

${ }^{219}$ Bill of Rights, s 25.

${ }^{220}$ Driver $v$ Radio New Zealand, above n 218, at [109].

${ }^{221}$ [2017] UKSC 49.
} 
with his family and their relations with the community in which he live[d]". But found that, ${ }^{222}$

The impact on PNM's family life of what was said about him at the trial is no different in kind from the impact of many disagreeable statements which may be made about individuals at a high profile criminal trial.

Going on to say,

The immunity and the privilege [allowing the disclosure of the information] reflect the law's conviction that the collateral impact that this process has on those affected is part of the price to be paid for open justice and the freedom of the press to report fairly and accurately on judicial proceedings held in public.

That decision was subject to a strong dissent by Lords Kerr and Wilson, in which they concluded: ${ }^{223}$

... this court needed first to recognise the risk to PNM that his identification would generate a widespread belief not only that he was guilty of crimes which understandably attract an extreme degree of public outrage but also that he had so far evaded punishment for them; and then, in consequence, to balance the risk of profound harm to the reputational, social, emotional and even physical aspects of his private and family life, notwithstanding that he is presumed by the law to be innocent and has had no opportunity to address in public the offences of which at one time the police suspected him to be guilty.

This position is further unsettled by the finding in Richard $v B B C$. In that case, Mann $\mathbf{J}$ found: 224

If the presumption of innocence were perfectly understood and given effect to, and if the general public was universally capable of adopting a completely open and broadminded view of the fact of an investigation so that there was no risk of taint either during the investigation or afterwards (assuming no charge) then the position might be different. But neither of those things is true. The fact of an investigation, as a general rule, will of itself carry some stigma, no matter how often one says it should not.

While the dissents in Khuja and the finding in Richard unsettle the area, multiple judgments, including them, are united by considering the harm potentially caused by the publication of law enforcement activity.

\section{Proposition two: the harm of disclosure is relevant}

The second proposition is, therefore, that harm is relevant to the reasonable expectation of privacy enquiry. On one hand, this is consistent with research about societal expectations of privacy. In Christena Eng-Nipperts Islands of Privacy she quantitatively investigated people's expectations of privacy. ${ }^{225}$ While no consensus formed of what people considered

${ }^{222}$ At [2].

${ }^{223}$ At [58].

${ }^{224}$ Above n 116, at [248].

${ }^{225}$ Christena Eng-Nipperts Islands of Privacy (Chicago University Press, Chicago, 2010) at 110-129. 
private, the two themes were the aforementioned closeness to a person's biographic core and the risk of harm. This is only controversial when we consider the harm in each of these cases.

This difficultly is clearly demonstrated in the United Kingdom case of $r e J R 38 .{ }^{226}$ In that case a teenager argued that a photo published recording sectarian riots was a breach of privacy. The photo was published in order to identify participants in the riot. Demonstrating the contentiousness of the area, the case ended in the Supreme Court. While the court unanimously dismissed the application, it was split on whether the applicant had a reasonable expectation of privacy. The majority, led by Lord Toulson, found that no person engaged in rioting activity could expect privacy protection. ${ }^{227}$ Separately, Lord Toulson acknowledged that a reasonable expectation of privacy might exist if the purpose of publication was something other than identification. Lord Kerr and Lord Wilson's dissent focused on the effect the publication would have on the applicant and the stigmatising effect of publication. ${ }^{228}$

In each of these law enforcement cases, the harm addressed by judges finding that there is a reasonable expectation of privacy appears to be the societal harm of people thinking less of the plaintiff. But this is reputational harm. While Lord Sumption raised the risk of harm to the applicant's family life, even this is mediated by the applicant's standing in society. Conversely, there is significant authority that privacy protections ought not to be used where the primary interest sought to be protected is reputation, in particular where a defamation claim would be unsuccessful. ${ }^{229}$

Even in New Zealand, where the Brown v Attorney General concerned a flyer distributed by police, notifying local residents that the plaintiff was a paedophile, it is difficult to see the harm as anything other than reputational harm. ${ }^{230}$ None of the other features from Murray v Express Newspaper were met. While it is easy to imagine Mr Brown would face relational difficulties, perhaps even family strife, this is all mediated by the reputational harm to him. Similar harm would occur to anyone charged with a morally repugnant crime who is factually innocent, yet they would be afforded no default reputational protection. Similar is true of people involved in civil proceedings who are required to reveal embarrassing facts within disclosure. This is because there is no general right to reputation.

\footnotetext{
${ }^{226}$ Above $\mathrm{n} 183$.

227 At [94].

228 At [53].

${ }^{229}$ See Terry v Persons Unknown [2010] EWHC 199 (QB) at [96] where Tugendhat J divides cases based on whether there is an inconsistency with defamation or not, with the greatest scepticism applied to those cases where the primary motivation is reputation and the claim is inconsistent with a defamation claim.

${ }^{230}$ [2006] NZAR 552 (DC).
} 
This then leaves us in a difficult position that reputational harm may be considered as a relevant factor to a claimed reasonable expectation of privacy, even absent other traditional privacy indicating factors.

\section{Proposition three: the timing of the publication is also relevant}

Finally, the timing of the publication is relevant; courts are more willing to acknowledge reasonable expectations of privacy over pre-charge and pre-trial material. ${ }^{231}$ While this is the case, pre-charge material may have stronger countervailing interests in publication, such as in $R e J R 35$ where the dissent acknowledged the necessity of the publication for the purpose of identifying the suspects.

\section{Conclusion on law enforcement material}

To conclude, potentially prejudicial law enforcement information should not be considered to be subject to reasonable expectations of privacy, absent other indications of privacy. That said, some forceful dissents have challenged this position. This uncertainty is significant for law enforcement reality television, because this content is the main feature of the shows. Shows like Police Ten 7 and Motorway Patrol are defined by interactions with people who are suspected of or caught doing prejudicial things. Even rescue shows touch on this information, as demonstrated by Andrews $v$ Television New Zealand where there is the clear implication that $\mathrm{Mr}$ and Mrs Andrews were not driving normally.

\section{G People Signal Expectations of Privacy}

As well as documentary reality television broadcasting traditionally protected subjects, involuntary participants also often signal expectations of privacy. While some subjects court attention, many subjects block cameras, make gestures, move away, close doors and hit cameras, all of which demonstrate desires for inaccessibility. For example, the topless teenager, discussed in the introduction, initially refused to get onto a rescue device available to bring her to safety. ${ }^{232}$ She clearly signals that this was because of the camera. Such signals are factual matters and it is outside of the scope of this paper to detail all of them. However, they align with the barriers discussed by Kirsty Hughes in her discussion of how behavioural cues signal expectations of privacy. ${ }^{233}$

This conduct conflicts with the widespread belief that documentary reality television is based on participant's consent to take part. The BSA's own research supports that consent

${ }^{231}$ See Cliff Richard v BBC, above n 116, at 246. Compare to Khuja, above n 221.

${ }^{232}$ Above $\mathrm{n} 1$.

${ }^{233}$ Kirsty Hughes, above n 181. 
is inconsistently obtained and that, in any instance, people frequently lack the context necessary to make an informed decision. ${ }^{234}$ Some people acknowledge coming across like they may have consented, but "in hindsight would not have done so". ${ }^{235}$ Subjects often lack the capacity to consent, due to intoxication or shock, as one subject of Piha Rescue puts it "[t]here was a camera but to be honest I wasn't really taking it in". ${ }^{236}$ Another participant said, that they were asked to be interviewed when they were in a "distressed state exhausted from their ordeal".237

BSA cases also disclose improper attempts to gain consent, these include persistent requests, misleading conduct and reliance on implied consent by stimulating a response. ${ }^{238}$ For example, in SW and Television New Zealand, a film crew attempted to obtain consent multiple times; meanwhile, they filmed undeterred by the subject's objections. The subject asked what the recording was for and they said, "Oh it goes out in New Zealand" and changed the subject, not revealing the show or its context. "She was obviously distressed and emotional" when she provided ambiguous consent 12 minutes later. ${ }^{239}$

Finally, consent is an aspect of self-determination, so when a subject is under compulsion, or there is a significant power imbalance, consent is not operative. This issue affects a lot of documentary reality television where subjects are under compulsion by authority or circumstance. A person, such as SW, while detained by law enforcement, cannot freely remove themselves from the filming or the situation.

Matters get worse when we review the material provided to participants. For example, the Greenstone TV online information for participants appears to be focused on providing reassurance than informed consent to participate in the filming. It starts by reassuring participants that because someone is filmed does not mean that he or she will be on television. ${ }^{240}$ It goes on to note that "[g]enerally, events taking place in public (e.g. on the motorway) don't have an expectation of privacy". It also includes the reassurance that "[h]owever, we'll never include personally identifying information about you (a passport number, or your full name or address, for example)". This statement is contrary to the ordinary or legal meaning of 'identifiable'. The presentation of people's image, often combined with a name, alongside pattern of life information and other material is undoubtedly sufficient to identify a person.

\footnotetext{
${ }^{234}$ Broadcasting Standards Authority “The Real Deal” (1 September 2011) at p 27.

235 At 30 .

236 At 30.

${ }^{237}$ Broadcasting Standards Authority, above n 234, at 30.

${ }^{238}$ SW and Television New Zealand, above n 53; PG v Television New Zealand, above n 56.

${ }^{239}$ SW and Television New Zealand, above n 53, at [29].

${ }^{240}$ Greenstone "Will I be on TV?" < http://www.greenstonetv.com/will-i-be-on-tv/>.
} 


\section{H Timing Matters}

The last matter affecting the expectation of privacy is the timing of the broadcast. Much documentary reality television is rebroadcast. This repetition allows broadcasters to sell advertising against footage multiple times and make more profit. This means sometimes material is published long after the filming, impacting the expectation of privacy.

There is some uncertainty about the proper point at which the reasonable expectation of privacy is assessed. ${ }^{241}$ There is support for the point of publication; however, there is also support for the point of filming. ${ }^{242}$ However, MQ and Television New Zealand and Tucker $v$ News Media Ownership Limited show that information, in particular criminal history, can become private over time. ${ }^{243}$ This means documentary footage, filmed in public circumstances could be subject to a reasonable expectation of privacy at some later point in time. This aligns with the concept that people should be able to move on and change from their past, one enshrined in various clean slate legislation. ${ }^{244}$ For this reason, the seven year period for minor offences is probably a good guide.

\section{Conclusion on the reasonable expectation of privacy}

This chapter has established that documentary reality television systematically deals with information which is traditionally subject to a reasonable expectation of privacy. This includes spatial areas and topics which are usually protected.

\footnotetext{
${ }^{241}$ Rogers $v$ Television New Zealand [2007] NZSC 9.

${ }^{242}$ At [48] per Blanchard J and [104-105].

${ }^{243}$ Tucker v News Media Ownership Limited [1986] 2 NZLR 716 (HC).

${ }^{244}$ Criminal Records (Clean Slate) Act 2004.
} 


\section{The Broadcast Content is Highly Offensive}

This chapter concerns the second element of liability: that the material published in documentary reality television is often highly offensive. While what is highly offensive is conceptually difficult, much documentary reality television content falls within prototypical examples of highly offensive content, where the publication is "truly humiliating and distressful or otherwise harmful to the individual concerned". ${ }^{245}$ This is particularly true when the broadcast strays into humouring, conflicting and mocking subjects, as well as using their situations to create salacious content.

Formerly there was a second component to the test, which is that there must have been widespread publication of the highly offensive content. Recently Henderson $v$ Walker confirmed that this is not an element of the tort, on the basis that even a limited disclosure could result in a significant breach of privacy. ${ }^{246}$ In any instance it is unnecessary to consider this element as a broadcast on mainstream television meets this criterion by definition.

The highly offensive test has been subject to significant academic criticism and negative obiter dictum remarks. However, it remains good law. The test was after all applied in the leading judgments in Hosking $v$ Runting and has been consistently applied by lower courts. ${ }^{247}$ The BSA also applies the highly offensive standard; requiring that the publication is "highly offensive to an objective reasonable person in the position of the person affected". ${ }^{248}$

The test comes from Hosking $v$ Runting, where the joint judgment of Blanchard and Gault $\mathrm{JJ}$ specifies "a procedural requirement that relief requires that a breach is highly offensive to a reasonable person". ${ }^{249}$ The justices based the requirement in the Restatement of Torts, Lenah Game Meats and English Court of Appeal's decision in Campbell v MGN Ltd. ${ }^{250}$ However, soon after Hosking $v$ Runting the English House of Lords removed the requirement from the English conception of the tort. ${ }^{251}$ The House of Lords acknowledged that the publication of private material was itself a cause of offensiveness. ${ }^{252}$ Since

\footnotetext{
${ }^{245}$ Hosking $v$ Runting, above $\mathrm{n} 11$, at [126].

${ }^{246}$ Henderson $v$ Walker, above $n 143$ at [207-217].

${ }^{247}$ See: Clague v APN News and Media Ltd [2012] NZHC 2898; Henderson v Slevin [2015] NZHC 366; Andrew v TVNZ, above n 62; Henderson v Walker, above n 143.

${ }^{248}$ Broadcasting Standards Authority, above n 152, Standard 10b.

${ }^{249}$ Hosking $v$ Runting, above n 11, at [113]

${ }^{250}$ At [42].

${ }^{251}$ Campbell v MGN Ltd [2004] UKHL 22 at [96].

${ }^{252}$ At [99].
} 
Campbell, the English position has been modified again by Murray $v$ Express Newspapers. ${ }^{253}$ Murray addressed the factors relevant to the assessment of the reasonable expectation of privacy and confirmed that one relevant factor is the effect of the publication on the claimant. ${ }^{254}$ This means that, while offensiveness is not required, it is a relevant factor to the determination of a claim.

The highly offensive requirement is intended to create a margin of appreciation for freedom of expression and to address the concern that "trivial invasions of privacy should not be actionable". 255

\section{A The Application of the Highly Offensive Test in Andrews v Television New Zealand}

As discussed in chapter two, a key point for the arrival in documentary reality television in New Zealand was the High Court case of Andrews $v$ Television New Zealand. The Andrews were successful at establishing a reasonable expectation of privacy, however, failed to establish that the publication was highly offensive.

In a controversial decision, Allan $\mathrm{J}$ was heavily sceptical of the offensiveness of the broadcast on the basis that the Andrews could not point to any specific facts that presented them in "a bad light". ${ }^{256}$ Indeed, he went so far as to say that Mrs Andrews was presented as "a caring person... concerned about her husband's wellbeing". ${ }^{257}$ This aligns with Professor Nicole Moreham criticism of the highly offensive test, where she argues that the test "obscures the fact that all privacy interferences "humiliate" their subjects — and undermine[s] their dignity and autonomy". ${ }^{258}$ It also misses the point made by the House of Lords in Campbell v MGN, that the broadcast itself is the bane, not the specific facts presented. Indeed, while Allan $\mathbf{J}$ focuses on the fact that Mrs Andrews cannot articulate which facts are embarrassing or hurtful, Mrs Andrews makes clear in her crossexamination that it was not the facts in the publication which was humiliating to her, it was the publication itself. ${ }^{259}$

However, this link between the publication and the content published also emphasises the key concern of Lord Nicholls in Campbell v MGN Ltd that the highly offensive test leads

\footnotetext{
${ }^{253}$ Murray v Express Newspapers, above n 183.

254 At [35]-[36]

${ }^{255}$ Hosking $v$ Runting, above n 11, at [255].

${ }^{256}$ Andrews v Television New Zealand, above n 62, at [67].

257 At [68]

258 Nicole Moreham, above n 245, at 22.

${ }^{259}$ Mrs Andrews' statement of evidence, Andrews v Television New Zealand [transcript] HC Auckland CIV2004- 404-3536, 15 December 2006, at [11]. Quoted in Jennifer Moore "Traumatised Bodies: Towards Corporeality in New Zealand's Privacy Tort Law Involving Accident Survivors" above n 63.
} 
to duplication and that the test was a "recipe for confusion". ${ }^{260}$ However, Andrews $v$ Television New Zealand represents the extreme delinking of these two tests and results in an equally unclear result. Following Andrews v Television New Zealand, this intertwined nature of the tests was acknowledged by Young $\mathrm{P}$ in the Court of Appeal decision Rogers when he said that "[i]n most cases it will be the defeating of a reasonable expectation of privacy which makes publication objectionable". ${ }^{261}$

Finally, as pointed out by Professor Moreham, most decisions following Hosking $v$ Runting have not explained the factors relevant to the decision as to what is highly offensive and what is not, suggesting that judges are treating the test as "judicial instinct". ${ }^{262}$ The most substantive reasoning is that of Whata $\mathrm{J}$ in $C v$ Holland, but his outcomes are still that the examination is broad and based on numerous factors. ${ }^{263}$ In assessing the highly offensiveness he does not list these factors, instead states that the particular intrusion in that case was clearly highly offensive. For these reasons, it is conceptually unclear what New Zealand judges are bearing in mind when they consider offensiveness. All of this said, the highly offensive test remains good law and therefore must be applied. For this we must return to the original statements in Hosking $v$ Runting which centre the tort on humiliating or degrading publication. ${ }^{264}$

\section{B The Core of the Test is Degrading or Humiliating Coverage}

The key areas where documentary reality television publishes highly offensive content are where it humours, humiliates or covers vulnerable people. However, the coverage itself displays a level of offensiveness, even absent these specific factors. Therefore, as a genre, documentary reality television frequently publishes material which is putatively highly offensive content. In particular, this includes content which is at the expense of involuntary subjects. For example, the topless teenager's rescue was used to create a humorous segment and was then used for marketing purposes. The camera is pointing down directly at her and within arm's length. She had to hold on so could not block the camera, instead she concealed her face. Even though she was clearly signalling a desire not to be filmed, the clip was included in the show. It was also published as online advertising, exposing her to a litany of negative and sexual comments. ${ }^{265}$

\footnotetext{
${ }^{260}$ Andrews $v$ TVNZ, above $\mathrm{n} 62$, at 22.

${ }^{261}$ Campbell $v$ MGN Ltd, above n 251.

262 Nicole Moreham, above n 245, at 14-15.

${ }^{263} C$ v Holland [2012] NZHC 2155 at 16.

${ }^{264}$ Hosking $v$ Runting, above $\mathrm{n} 11$, at [126].

265 Bondi Rescue "Bondi Lifeguard Whippet Rescues A Topless Woman" (10 July 2011)

$<$ https://www.youtube.com/watch?v=yPIIJfqsGNc>.
} 
The episode of Water Patrol where Maritime Police interdicted a boat in the Marlborough Sounds is another example. The boat was in a secluded area when the Maritime Police arrived for the purpose of creating entertainment television. ${ }^{266}$ The occupant's state of undress was drawn upon for creative purpose against his best interests. The officers and the voice narrator comment on his partial nudity, ridiculing the situation. The BSA noted that the clear purpose of the interdiction had been to make a humorous television at the man's expense.

These are an extreme examples, but less extreme examples still exemplify humiliating situations being used to create entertainment content.

\section{Humouring Involuntary Participants}

When documentary reality television arrived in New Zealand it was quite a serious genre. Shows such as Cops involve humour, but it is drawn out from situations rather than added by the commentary. Aside from the broadening of the genre, New Zealand also appears have contributed by adding humour to it. The commentator will frequently add jokes or make plays on words to draw attention to particular features of the show. A person bringing honey to New Zealand faces a fine which is "a not so sweet surprise"; an officer who spent his morning at a car crash has had "a smashing start to the day"; a driver going to lose her car she called "Lou Lou", "is now Gone Gone". ${ }^{267}$ These humorous asides add a light and entertaining feel to the shows. However, often this humour from making light of the negative experiences of the participants.

Even when the humour is not at the expense of the subjects, it is still making light of people's serious situations. The owner of Lou Lou was in the process of losing her car and being arrested. ${ }^{268}$ Her situation is immortalised for the entertainment of others.

A common target for humouring involuntary participants is people who are drunk. Whole segments are frequently focused on agencies engaging with people who are intoxicated. ${ }^{269}$ While these people may be in public places, which may reduce their expectation of privacy, their position in a public place should not affect the offensiveness of using their intoxication

\footnotetext{
${ }^{266} P G$ v Television New Zealand, above n 56, at [25-26].

267 "Road Cops" (2015) Starfish Pictures Ltd, Series 4, Episode 10.

${ }^{268}$ As explained later in the episode she was however released without charge.

269 This trend is fairly international. For example, see Customs UK Series 2 Episode 9 or Random Breath Test Season 8 episode 4. One of the more interesting features of this last example is that the officer pulls the driver away for a conversation on his own, creating a perception of privacy, but the conversation is picked up by a microphone on the officer and broadcast. The clear purpose of pulling the participant away from other people was to create a perception of seclusion.
} 
for commercial entertainment. Particular examples include film crews filming heavily intoxicated people throwing up or having wet themselves.

\section{Humiliation and Degrading Coverage}

Aside from humour, media lecturer Richard Kilborn argues that reality television is appealing because "of the dubious delight we take in others' discomfiture but also because of the viewer's knowledge that he or she could be... the star of the show". ${ }^{270}$ But viewer research supports the view that documentary reality television viewers very much appreciate that they are not the centre of the show. ${ }^{271}$ They report this due to the humiliating and degrading content they acknowledge. ${ }^{272}$ One viewer going so far as to say, "if you had to seek permission, you wouldn't have any shows'. ${ }^{273}$ The BSA concluded that people are fine with the genre precisely so long as it was "not them". 274

This is because people portrayed in these shows come across as "dumb", "naive", and that as "real idiots up there that you can have a real good laugh at". ${ }^{275}$ One participant summing it up that "I'm sure people watch it just "cause they like to laugh at the silly people". ${ }^{276}$ People watch to observe "naming and shaming" and justice against subjects, and these motivations would be lost if people were only presented in good light. However, this "justice" is presented without appeal or right of reply; it is governed by the rule of entertainment rather than the rule of law.

From a participant's viewpoint the shows "[k]ind of made you feel like a criminal". ${ }^{277}$ In the same episode as that statement, an exchange occurs where a dog handler is questioning a person upon whom the dog made a positive drug indication: ${ }^{278}$

Dog Hander: "What was the last drug you used?"

Passenger: "Ah, I am not really a drug user."

Dog Handers: "Yeah yeah, what did you use? Cocaine?"

People are pressed and presented as a threat to New Zealand and guilty of crimes, without a right of reply or access to counsel. This starts with the very introduction to the shows:

\footnotetext{
${ }^{270}$ Richard Kilborn "How real can it get” (1994) European Journal of Communication, 9 (4) 421 at 424.

271 "Border Patrol”, Greenstone, Series 7, episode 1.

272 Broadcasting Standards Authority, above n 234.

273 At 15

274 At 8 .

275 At 8-10.

276 At 10.

277 “Border Patrol", Greenstone, series 7, episode 1.

278 There may have been some response from the passenger confirming drug use, however the final cut shows a clear suggestion of guilt against the participant's statement.
} 
New Zealand's air, sea and land borders are persistently under attack. Drugs, prohibited goods, pest organisms and animal diseases are among the unwanted and the unwelcome that could destroy our economy and our whole way of life. Standing in their way are our defenders: the men and women of customs and the Ministry of Primary Industries. Crucial lines of defence New Zealand's Border Patrol.

This could be framed as reputational harm, but another way of viewing it is that people are reduced to caricatures, incapable to provide balance. This alone creates a level of offensiveness.

\section{E Vulnerability}

Vulnerability is also a basis for offensiveness. This is demonstrated by the American case, Daily Times Democrat v Flora Bell Graham, where the plaintiff's dress was blown up by the wind, revealing her undergarment in public. ${ }^{279} \mathrm{~A}$ picture was taken and published in the local news. The plaintiff was successful in establishing that the photograph was offensive and that such a photo, taken in a moment of vulnerability, would offend a person of reasonable sensibilities. This is relevant to documentary reality television, as much of it is filmed when participants are in moments of vulnerability.

Particular vulnerability is experienced in rescue and first aid situations. Rescue situations are intrinsically marked by an inability to escape and risk of bodily harm. People in Piha Rescue describe being in a state of panic and the situation passing like a blur. Filming in these instances is capturing people in some of their worst moments, as discussed above, but also in the moments that they are least able to react and to rationally consider the implications of filming.

The same is true of people requiring first aid. First aid is defined by the absence of an ability to wait for primary care, such as visiting a general practitioner or hospital. On this basis it is defined by vulnerability and necessity. For instance in Shulman \& Ors v Group $W$ Productions a person had been involved in a serious crash. ${ }^{280}$ She was filmed while she received care. Her conversations with medical staff were picked up by a wireless microphone including her saying, "I just want to die". The coverage was held to be highly offensive and intrusive. This is consistent with the position that people requiring first aid are often in a state of shock or significantly concerned about their own health such that they are unable to retreat or consider their own interest. However, in documentary reality television these situations are monetised.

${ }^{279}$ Daily Times Democrat v Flora Bell Graham 162 Supp 2d 474 (1964).

28055 P 2d 469 (Cal 1998), cited in Andrews v TVNZ, above n 62, at [85-90]. 
Internationally, there are also examples where individuals are recorded engaging in selfharm. For example, in Nothing to Declare $U K$ a person is caught smuggling cocaine, she is filmed as she aggressively hits her head against a table. ${ }^{281}$ Examples such as this align with the significant concern raised by the courts in Peck $v$ the United Kingdom about the publication of material about an individual following a suicide attempt. ${ }^{282}$ No such examples are noted in New Zealand.

\section{F Offensiveness as a Result of the Collection}

Even when the material is not humouring, humiliating or degrading, or covering vulnerable people, offensiveness is generated by the means of collection. As demonstrated by chapter three, much of documentary reality television is filmed during traditionally protected interactions. The offensiveness of the situation should be considered in light of the interaction. Elements such as the involvement of public functions, the use of concealed cameras and the targeting of people who have requested support all fundamentally undermine standard expectations around filming of people. Examples such as the use of sophisticated drug detecting equipment and sniffer dogs, represent the powers of the state being used, in part, to develop commercial entertainment. ${ }^{283}$

\section{G Offensiveness Explored: Ali v Channel 5}

All of these matters united in the recent English case of Ali $v$ Channel 5. The dispute concerned the show Can't Pay We'll Take Away which focuses on the jobs of High Court Enforcement Officers. It is a successful show, now in its sixth season.

The role of High Court Enforcement Officers (HCEO) is delegated under the Courts Act 2003 (UK) granting them the power to enter homes, take property, and evict people from properties. In 2004, the HCEO role was tendered out to private companies. ${ }^{284}$ These companies have developed into sophisticated enforcement providers with a full in-house solution for locating assets, taking them and securing them. This includes automatic information sharing between the Motor Vehicle Registration Department and HCEOs, so they can immediately identify the owner of a vehicle for repossession.

\footnotetext{
281 "Nothing to Declare UK" (2008) Favourite Films.

282 Peck $v$ United Kingdom, above n 202.

${ }^{283}$ People also have limited power to respond and, again, viewers are rarely told of the risk of false positive indications.

284 See Robert Turner "New Sheriffs" in England and Wales - An Account of the New High Court Enforcement Regime and the Creation of the High Court Enforcement Officers" (2012) 23(1) European Business Law Review 121.
} 
Direct Collection Bailiffs Limited is a HCEO provider. In 2015, Direct Collection Bailiffs Limited was assigned a writ of repossession over the home of $\mathrm{Mr}$ and Mrs Ali. ${ }^{285}$ As well as being HCEOs, Direct Collection Bailiffs Limited has an agreement to make Can't Pay We'll Take Away. As part of the agreement, HCEOs are filmed doing their jobs. Standard body cameras HCEOs wore for safety purposes were replaced by higher quality cameras used for the show.

The HCEOs arrive at Mr and Mrs Ali's home and tell them of the eviction. The eviction is filmed for a special edition of the Can't Pay We'll Take Away called Britain on Benefits. Before the eviction, one of the officers makes an assessment to the camera that the landlord wants "to see the tenants suffer". The claimants were unprepared for the visit. Mr Ali had just woken up and was only partially dressed. As the HCEO and the cameras crew walk through the house, they focus on the messy and untidy living conditions. A suggestion is made that the claimants are subletting the property and keeping the rent. The landlord's son taunted the claimants throughout the eviction.

The show was broadcast to 9.65 million people with the synopsis about the "the eviction of a seemingly gentle tenant from hell". ${ }^{286}$

As the claimants are packing, one of the HCEOs repeatedly stated his belief that the Ali's were in the wrong and told the landlord's son that this was his opportunity to say what he wanted to say to the tenants. ${ }^{287} \mathrm{He}$ comments to his colleague: "can I just get through, cos I can pour some petrol on the situation". ${ }^{288}$ Then once the eviction has occurred, that HCEO is recorded saying "[i]t's good though it's terrific television" before the following exchange: ${ }^{289}$

HCEO: What we need is a bit of fisticuffs really.

Police Officer: If one of them gets arrested.

HCEO: Yeah, we'll do that.

In contrast, at multiple times the claimants objected to filming. ${ }^{290}$ The claimants complained about the breach of privacy. Whilst they succeeded, ultimately the cost award against them was greater than the damages they received.

In terms of offensiveness, the claimants experienced vulnerability in multiple ways. Mr Ali had just woken up and was partially undressed. There was also the fact that they were the only participants in the interaction that lacked forewarning, they are uniquely unprepared.

\footnotetext{
${ }^{285}$ Ali v Channel 5, above n 99.

286 At [1] and [119].

${ }^{287}$ At [77] and [114].

288 At [85].

289 At [111].

${ }^{290}$ At [172-179].
} 
They are immediately positioned as the villain of the drama. Their viewpoint or legal predicament was not put forward in the broadcast. ${ }^{291}$ Indeed, this was the very issue undermining the claim to the public interest, because the show did not critically engage with the topic. This has caused some to term to sub-genre as "poverty porn" for its gratuitous display of poverty, without critical engagement, for entertainment purposes. ${ }^{292}$

But, finally, Ali v Channel 5 demonstrates the offensiveness of the production taken as a whole. The situation was the arrangement directly engaged with the institutions of justice. The High Court Enforcement Officers were equipped with the power of the state, a writ of the High Court and uniforms of power. The same people inflamed the situation for the purpose of entertainment television. The situation was then broadcast without genuine balance or empathy for the view of the involuntary participants.

291 Ali v Channel 5, above n 99, at [196].

292 Tracey Jensen "Welfare Commonsense, Poverty Porn and Doxosophy" (2014) 19(3) Sociological Research Online 1. 


\section{The Breach is Not Answered by Any Defence}

So far this paper has established a framework for breach of privacy as a right. It has then established that documentary reality television frequently contains characteristics which meet the test for liability. However, the highly offensive publication of material over which there is a reasonable expectation of privacy could still be lawful if there is an applicable defence.

\section{A What is a Defence?}

There are multiple meanings of 'defence'. ${ }^{293}$ In a broad sense, one can talk about anything a defendant puts forward in support of their case. In the narrow sense, the word means the specific legal elements that negate liability. This chapter concerns the narrow sense of the term. Specifically, the potential defences to a breach of privacy by broadcast contained in documentary reality television.

The orthodox position is that there is a single defence to a claimed breach of privacy: public concern. This chapter starts by considering that defence. It also continues to argue that a review of cases and BSA complaints reveal the outlines of further defences being pleaded, sometimes successfully. This is the defence of illegality, which is a longstanding general defence in privacy law. This chapter concludes that it is entirely consistent that this defence applies to privacy complaints. It argues that it should be expressly acknowledged by the courts as applicable. Doing so maintains consistency with general private law and avoids the need for special privacy specific rules to address plaintiff conduct. Acknowledging the defence also clarifies the onus of proof for parties to the dispute.

\section{B Public Concern}

The existence of the public concern defence is confirmed in Hosking v Runting. Its purpose is to provide a safeguard for free expression in the public's interest. This contrasts earlier decisions, such as $P \vee D$, where the lack of public interest was a substantive element of the tort. ${ }^{294}$ The defence is intended to create a climate in which important issues can be discussed and debated. As discussed in chapter five there is a strong and a weak form of this argument. ${ }^{295}$

The weak public interest defence focuses on the material which is genuinely of public concern, such as serving public interests, democratic discussion and public safety. The

293 J Goudkamp, Tort Law Defences (Oxford, Hart Publishing, 2013).

${ }^{294} P$ v $D$ [2000] 2 NZLR 591.

${ }^{295}$ Contrast $A v B$ [2002] EWCA Civ 337 and Campbell $v$ MGN Ltd [2004] UKHL 22. 
strong form argues that in order to have a functioning free media, the media must be able to sell a commercial product, which includes matters outside of the serious topics of the day. While applying some latitude for editorial discretion, New Zealand has adopted the weak defence. ${ }^{296}$ The material covered by the defence must be genuinely in the public's best interest, not merely matters of public curiosity. ${ }^{297}$

Another question regarding the defence is the status of commercial speech. In Hosking $v$ Runting Tipping $\mathrm{J}$ said the defence is not intended to cover material which is intended to "boost circulation". ${ }^{298}$ However, in Hosking, Gault P found that it is not valuable to categorise speech and that each broadcast must be considered on its own merits. ${ }^{299}$ Read together, this means commercial speech is less likely to be covered by the public interest defence, but there is no categorical rule against it.

This particularly affects documentary reality television because of its overt commercial and entertainment focus. As demonstrated by chapter three, documentary reality television is inseparable from its commercial and entertainment purposes. This focus is enshrined in the very production agreements for the shows. While Andrews $v$ TVNZ found that entertainment purposes are not necessarily fatal to public concern, they do taint the purely public purpose of the defence. ${ }^{300}$

Furthermore, while news activity is afforded greater public interest, documentary reality television is not news. It is not even particularly factual. Crime is overrepresented, so is the diversity of those in power; crimes by minority groups are exaggerated and so is street crime. ${ }^{301}$ In many ways, the level of content also goes beyond news material. ${ }^{302}$

\section{Documentary reality television is not news}

News is defined by the factual account of new material, usually of some import. Not only does documentary reality television have aspects that go beyond this; it has aspects that are antithetical to news activity. ${ }^{303}$ For example, shows are traditionally rebroadcast multiple times, in some circumstances years after the facts concerned. This is inconsistent with news activity. For example, one Police Officer who achieved fame through the genre described the celebrity as "surreal", because the events portrayed in the episode occurred five years

\footnotetext{
${ }^{296}$ Andrews $v$ TVNZ, above n 62, at [87-88] citing Auckland Area Health Board v Television New Zealand Ltd [1992] 3 NZLR 406 at 407.

${ }^{297}$ Hosking $v$ Runting, above $\mathrm{n} 11$, at [129].

298 At [258].

299 At [135].

${ }^{300}$ Andrews $v$ TVNZ, about $\mathrm{n} 62$, at 91.

301 See footnote 40.

${ }^{302}$ Andrews $v$ TVNZ, about n 62, at 64.

${ }^{303}$ Director of Human Rights Proceedings v Dotcom [2019] NZHRRT 22 at [32-37].
} 
previously and the episode had already been broadcast once before, three years ago. ${ }^{304}$ Same is true in $M Q v$ Television New Zealand, discussed in chapter two, where the man who had formerly been addicted to drugs successfully challenged Police Ten 7, when the show was rebroadcast ten years after the fact. ${ }^{305}$ An addiction epidemic or drug-taking may be of public interest at the time, but 10 years after the fact the representation is inaccurate and out-of-date and all that is left behind is the entertainment purpose.

In the same way, international syndication also runs against the contents being considered news activity or of public concern. This is because if the purpose of the genre is to inform people of local events, it is nonsensical that the shows are being sold globally as a commodified export. This is particularly acute given much of New Zealand's reality television is filmed within small areas of New Zealand, such as South Auckland, Auckland Airport and South Otago.

However, even if some limited content is of news value, it is important to bear in mind that content's news status is not necessarily fatal to a legitimate expectation of privacy. The public concern must cover the specific content contained in the broadcast and be sufficient to outweigh the subject's reasonable expectation of privacy. ${ }^{306}$ This nexus between the public concern and the particular content will rarely be met, because of the extent of coverage contained in the genre and the competing entertainment motivations that go into the content and presentation of the broadcast. This additional influence on entertainment inclusions may colour the broadcast and mean it has exceeded what is strictly in the public concern.

\section{Public concern about public safety}

In Andrews v TVNZ Allan J did make obiter dictum comments that public safety messages could satisfy the public concern defence. ${ }^{307}$ These comments are not central to the case because Allan $\mathrm{J}$ had already found that the broadcast was not highly offensive, meaning no defence was applicable. However, this is important because documentary reality television is frequently framed by its public safety messages. Firefighters taught people about fire risk, Border Patrol teaches people about border security, Motorway Patrol teaches people about the dangers of speeding and drunk driving. However, the argument's weight is doubtful when we consider the public safety message in Andrews $v$ TVNZ. Directly prior to the crash scene, the show's focus was on pranks in the firehouse. Furthermore, a

304 Breakfast "Paul Henry Interviews the Blow on the Pie Guy on Breakfast" (23 October 2009), $<$ https://www.youtube.com/watch?v=132ADJOr3RY>.

${ }^{305}$ MQv Television New Zealand, above n 58.

${ }^{306}$ Andrews $v$ TVNZ, above n 62, at [86]. Hosking v Runting, above n 11, at 129.

${ }^{307}$ Andrews $v$ TVNZ, above n 62, at [80-92]. 
mitigating factor against the offensiveness of the broadcast was that the material broadcast did not disclose the causes of the crash or the fact Mr Andrews had been drinking. These facts undermine the footage being a serious and complete public safety message.

\section{The Basis Illegality as a Defence}

While judicial precedent in New Zealand has only focused on the public concern defence for privacy. This chapter goes on to consider illegality as a general private law defence. Illegality or ex turpi causa non oritur action, is the longstanding principal that, "No court will lend its aid to a man who founds his cause of action upon an immoral or an illegal act." ${ }^{308}$ For example, a burglar will not have a cause of action against his negligent accomplice. ${ }^{309}$ Neither will they be able to recover damages from their getaway driver that crashes the car during the escape. ${ }^{310}$ While not formally acknowledged in privacy decisions to date, there are multiple examples of it being considered in disputes and it was considered in Andrews $v$ TVNZ under the heading of plaintiff culpability. ${ }^{311}$

To consider the basis of illegality as a defence, it is worth returning briefly to the concept of privacy as a claimable right. A person has a claim where another person has a correlative duty towards them. ${ }^{312}$ A defence to a claim can undermine the right, the duty or both. Illegal or significantly wrongful actions undermine the claim resulting from any loss, meaning a person no longer has a claimable right. While the defendant may have a moral duty towards the claimant, the courts are unwilling to enforce claims made by those undertaking illegal actions. As it undermines a general claim in private law it should also defend a privacy claim.

While there is some commentary that the plaintiff's act must be criminal or involve significant moral turpitude, the courts have expanded this scope to require a case-by-case analysis. ${ }^{313}$ For example, in Brown $v$ Dinsmuir a property developer undercut his neighbour's property, the neighbour then replaced soil on the property developer's land, and the property developer sued for trespass. On appeal Penlington J acknowledged that

\footnotetext{
${ }^{308}$ Holman v Johnson (1775) 1 Cowp 341 at 343 per Lord Mansfield.

${ }^{309}$ Example from National Coal Board v England [1954] AC 403.

310 Ashton v Turner [1981] QB 137.

311 Andrews $v$ TVNZ, above n 62, at [42-47].

${ }^{312}$ Wesley Newcomb Hohfeld "Fundamental Legal Conceptions as Applied in Judicial Reasoning" (1917) 26(8) Yale Law Journal 710.

313 Brown v Dunsmuir [1994] 3 NZLR 485.
} 
the illegality of undermining the defendant's property was a minor transgression, lacking moral turpitude, it was enough to satisfy the defence.

Within privacy, these claims of illegality are traditionally made under the reasonable expectation of privacy inquiry or concerning public interest. Plaintiff culpability was dealt with extensively in Andrews $v$ Television New Zealand. There the plaintiffs had crashed their car following an evening drinking at a party and there was the suggestion that they had been distracted at the time of the crash. ${ }^{314}$ Allan $\mathbf{J}$ applies this consideration to the highly offensive test and the defence of legitimate public concern. ${ }^{315}$ To this end, he cites Australian Broadcasting Corporation v Lenah Game Meats as authority for the proposition that a privacy claim must be assessed in the context of "contemporary standards of morals and behaviour", and goes on to discuss this under the heading "plaintiff culpability", which he states is equivalent to "blameworthiness" and "inequity". 316 The matter ultimately did not need to be resolved because Andrews failed to establish that the publication was highly offensive.

Illegality defences are frequently run in the BSA. For example, in Johns and Television New Zealand, the broadcaster argued that "[i]f there was any ridicule brought to bear, it was only through the woman's own behaviour" and that "it could not be blamed for her presence in the police station that evening". 317

It was also alluded to in Campbell v MGN Ltd where Ms Campbell was undertaking treatment for drug addiction. She had publicly claimed her sobriety. It was conceded by Ms Campbell that the newspaper was entitled to publish minimal details to inform the public of her hypocrisy and illegality.

However, while the defence of illegality is a general private law defence. It only applies to the direct and inevitable consequence of illegality. ${ }^{318}$ For example, if a security camera recorded an intruder on a property any intrusions caused by the filming would be undermined by illegality. But, it does not provide a general waiver for all actions. So a property owner who punches a trespasser can still be guilty of assault.

This requirement for the illegality to directly cause the breach ultimately undermines the application of illegality to most documentary reality television, for the lack of direct correspondence between the illegality and the broadcast is stark. For example, in Johns and

\footnotetext{
314 Andrews $v$ TVNZ, above n 62, at [5].

315 At [47].

${ }^{316}$ Australian Broadcasting Corporation v Lenah Game Meats [2001] HCA 63 at [42].

317 Johns v Television New Zealand BSA Decision No 1999-201, 11 November 1999.

${ }^{318}$ Leason v Attorney-General [2013] NZCA 509.
} 
Television it is impossible to say that the publicity was a direct consequence of the person's actions. Their actions may have led to them being in the police station, but did not directly lead to the broadcast. It would also not standardly be expected that such publicity was an outcome of being recorded in a police station. So to, for the Andrews; the publicity and intrusive recording was not a direct outcome of crashing the car, but was caused by the intervening actions of the film crew.

This requirement for the claim to be a direct consequence of the wrongful action explains why Brown v Attorney-General was a sustainable breach of privacy even though the claim was brought by a convicted paedophile regarding details of his misdeeds. ${ }^{319}$

A review of the BSA decisions concerning potentially disreputable behaviour also reveals that ex turpi may also be considered at the remedies phase. For example, in Johns and TVNZ the authority did uphold the complaint and did make orders. However in ordering compensation of $\$ 500$, the BSA referenced the "high element of risk involved in her behaviour". ${ }^{320}$ Similar occurred in $G$ and Television New Zealand where the BSA found the mistaken disclosure of teenager's engagement with the police recognised "that their presence was a result of the risky personal behaviour in which [the plaintiff's daughter] had engaged". ${ }^{321}$ There the BSA found a breach, but made no orders for compensation.

\section{Conclusion}

For these reasons, public concern is a limited defence vis-à-vis documentary reality television. While this paper argues that illegality should be considered an operative defence, as it is with other private law actions, it rarely applies to the genre.

319 Brown v Attorney General, above n 85.

${ }^{320}$ Johns $v$ Television New Zealand, above n 317.

${ }^{321} G$ v Television New Zealand BSA Decision No 1999-229, 9 December 1999. 


\section{So Why Are People Not Suing?}

So far, this paper has established a framework for breach of privacy in chapter five. Chapters six and seven established the first two pillars of liability in this framework. In the last chapter, it was established that there are fundamental conceptual issues in applying applicable defences to the genre. All of this brings forward the question: why are people not suing?

\section{A Returning to Ali v Channel 5}

One response to this question is to return to the outcome of Aliv Channel 5. When we left off in chapter 7 Justice Arnold ordered Channel 5 to pay $£ 20,000$ to Mr and Mrs Ali for the breach of their privacy. ${ }^{322}$

In the lead up to the litigation Mr and Mrs Ali had refused a settlement offer for more, monetarily, than $£ 20,000$ - which is relevant to consideration of court costs. ${ }^{323}$ The court did not accept the Ali's distinction that the settlement did not offer an admission of guilt or apology. ${ }^{324}$ The result of this was that while they were successful, they were also liable for costs following the settlement offer. ${ }^{325}$ This means, in all, the dispute for costs was more monetarily significant than the damages awarded so they lost money.

The case, which is a paragon example of offensive publication, was overwhelmed by the costs associated with it. Unfortunately, this is not a unique situation. On the other side of an involuntary participant is a well-resourced litigant with the ability to sustain litigation and pursue appeals. But, if we progress straight to the litigation difficulties, we miss the first issue for involuntary participants - learning of the broadcast.

\section{B The Issues}

\section{Notice of the impending broadcast}

A common trend between the disputes in the prior chapters is that the involuntary participants were unaware of the intended broadcast's purpose or lacked advanced notice of the broadcast. This lack of notice is key in three respects. First, it is broadly

\footnotetext{
322 That is to say, $£ 10,000$ each, not $£ 40,000$ between them.

${ }^{323}$ Ali v Channel 5 (costs) [2018] EWHC 840 (Ch).

324 At [51].

${ }^{325}$ Fortuitously for them, Channel 5 had failed to file a costs budget, meaning it was only entitled to $50 \%$ of assessed costs.
} 
acknowledged that monetary damage is not a substitute for a breach of a right, such as privacy. Second, the lack of notice reduces the options for negotiated solutions. If an opportunity is available and the producer is forewarned of a controversial segment before the final cut, then that segment could be substituted out for a different story. Once the final cut is broadcast, there is no such opportunity for a pragmatic easy resolution. Finally, the lack of pre-publication notice removes the ability to apply to the courts for injunctive relief.

\section{The cost is prohibitive}

The cost of civil proceedings is prohibitive for most people. Issues with access to justice and the cost of litigation are broader than privacy; but privacy is particularly affected by the cost of litigation due to the uncertainty of the area and the amount of legal work required for even a basic dispute. The Ministry of Justice recently published consultation noting that many considered it uneconomic to litigate any contested claim under $\$ 100,000 .{ }^{326}$

This issue strongly supports a low-cost alternative dispute resolution model, such as the BSA. Even then, however, the process of complaining still takes substantial time and commitment especially when most awards for breach of privacy range between $\$ 500$ and $\$ 1000$. Indeed, the maximum the Authority can award for a breach of privacy is $\$ 5000 .{ }^{327}$ For broadcasters, advertising slots range from $\$ 200$ to $\$ 19,000$ per national 30 -second slot. ${ }^{328}$ This means, in some segments, a maximum award could be paid back in under 10 seconds of placed advertising.

\section{The uncertainty is significant}

It also has to be acknowledged that 15 years on from Hosking $v$ Runting there is still no confirmed test for the tort. ${ }^{329}$ The application of the highly offensive test is profoundly unclear - with decisions on the standard lacking detail and consistency. Two recent cases, Clague v APN News and Media Ltd and Henderson v Slevin, have applied the tort using the Hosking $v$ Runting conception of the test, however, both were unsuccessful. ${ }^{330}$ Henderson $v$ Walker, was successful, as discussed above, but modified the requirements of the tort. This leaves the tort uncertain.

\footnotetext{
326 The Rules Committee Improving Access to Civil Justice (19 December 2019) at [36].

${ }^{327}$ Broadcasting Standards Act 1989, s 13(1)(d).

328 “Television \& Steaming Video on Demand” Performance Media <http://www.performancemedia.co.nz/television.html>.

${ }^{329}$ Also see Roger $v$ TVNZ [2008] 2 NZLR 277 (NZSC) where multiple members of the Supreme Court refused to confirm the elements of the tort.

${ }^{330}$ Clague v APN News and Media Ltd, above n 247; Henderson v Slevin, above n 247.
} 
Breach of confidence may also vindicate privacy rights, but still comes at a cost. Furthermore, it would require that the involuntary participant establishes that the information was gained in confidence and that the confidence has been breached. These elements would require substantial pre-litigation research, rendering the action inappropriate in most instances.

These issues centre on an involuntary participants ability to challenge a broadcast due to structural and financial limitations, rather than the justice of their claim. They are also related to the case-by-case determination of privacy disputes. Therefore two things that could address the situation are mandatory pre-broadcast notices and representative actions, but the best solution would be proactive investigation or leadership regarding the involvement of the public sector in the genre.

\section{The Solutions}

\section{Mandatory pre-broadcast notification}

Mandatory pre-broadcast notification could be enacted through the Broadcasting Standards. Advanced notification would have a trivial effect on the genre if the Broadcasting Standards were already operating as intended, because participants would already have advanced notice through the consent requirement. However, the disputes discussed in this paper and the BSA's own research supports that this is not occurring effectively.

\section{Representative actions}

Alternatively, the genre could be addressed by a representative action. In 2016, the new High Court Rules enabled parties to be joined to proceedings within representative classes of people who are affected by similar issues. ${ }^{331}$ Actions can either be brought by the consent of the people involved or as directed by the courts. Uptake of these proceedings has, to date, mainly been for product liability, particularly for building products. ${ }^{332}$

The policy behind representative action is that it enables plaintiffs to group together to form a class in common and to share the cost of litigation. In turn, representative actions also reduce the resource demand on courts, by avoiding the need for each case to be considered separately. This means that representative actions are most suitable when the legal area is

\footnotetext{
${ }^{331}$ High Court Rules 2016, r 4.24. Prior see to the High Court Rules 2016: Commerce Commission v Carter Holt Harvey Ltd [2008] 1 NZLR 387 (HC).

${ }^{332}$ Nikki Chamberlain "Class Actions in New Zealand: An Empirical Study” (2018) 24 (2) NZBLQ 132; Houghton v Saunders (2008) 19 PRNZ 173 (HC).
} 
uncertain, there is substantial legal work required to bring a claim, and the remedial awards are low (on a per claimant basis). Privacy is an example of such an area.

Previously, the High Court has been unwilling to form a class without the individual claimants opting into the action. ${ }^{333}$ An opt-out approach would allow a class to form based on a description of those involved. Such an approach makes it easier to form a representative action. It is easier to form opt-out representative classes, because they require less proactive action by the participants. Furthermore, because of the diverse nature of the class, potential claimants would need to do substantial work to identify other potential parties. These policy considerations were recognised by the Court of Appeal in Ross $v$ Southern Response, which allowed an opt-out class to form. ${ }^{334}$ The court acknowledge that, ${ }^{335}$

Allowing representative proceedings to proceed on an opt out basis will also strengthen the incentives for insurers and other large entities dealing with the public to comply with the law, as it increases the prospect that they will be held to account for any breaches of their obligations to large numbers of individuals in circumstances where individual claims may not otherwise be pursued.

The Supreme Court has accepted the appeal and is expected to consider the case this year. ${ }^{336}$

Documentary reality television is an ideal example of an area which meets the policy needs for an opt-out action. Aside from the fact specific nature of some disputes, the problem statements contained above are almost entirely aligned with the objectives listed in Ross $v$ Southern Response. This is especially true for any generic claim about the genre, such as the defective consent mechanisms or the disclosure of information collected by public authorities.

There is the potential that a representative action would not be required if a test case were to provide adequate resolution regarding the legality of the genre. The downside of this approach would be that the parties would bear substantial cost and uncertainty. But, were this to occur, the doctrine of stare decisis would reduce uncertainty for future litigants.

\footnotetext{
${ }^{333}$ Ross v Southern Response [2019] NZCA 431.

${ }^{334}$ Southern Response Earthquake Services Limited v Ross [2019] NZSC 140.

${ }^{335}$ Ross $v$ Southern Response (CA), above n 333, at [99].

${ }^{336}$ PG v Television New Zealand, above n 56.
} 


\section{Increase the remedial powers of the BSA and introduce own motion powers}

As discussed above, the remedial powers of the BSA are insufficient to incentivise compliance with the Broadcasting Standards. Their decisions reveal several examples where the activities of production companies are not only failing to meet the Broadcasting Standards, but also are contrary to the very foundations of the standards. For example, when a film crew actively conceals the purpose of the filming, the clear motivation is that if they were transparent the participant would object. Another example is where a film crew films against expressed objection. ${ }^{337}$ Actions such as these demonstrate active measures to circumvent standards and the ability of involuntary participants to retreat. The BSA's remedial powers could be enhanced, alongside providing the power for the BSA to undertake own motion investigations where significant breaches are suspected.

\section{Investigation by the Privacy Commissioner}

The ideal solution would be a non-juridical solution. One would be that the Privacy Commissioner completes an inquiry into the area. The Privacy Commissioner holds both a general power to inquire into any matter involving privacy and holds a general function to promote privacy. ${ }^{338}$ While the Privacy Act excludes news media activity from the definition of agency; first, documentary reality television is not news activity, and second, the Privacy Commissioner's functions are not restricted to defined agencies. It is understandable that the Privacy Commissioner could be hesitant to step into the role of the being a media regulator-however, this is already within his statutory function.

\section{Resolution by the Solicitor General}

This paper has also considered the legality of the arrangements and therefore, where the agencies taking part are government ones, the matter also falls within the functions of the Solicitor-General, whose role includes proactively supporting Government Departments on the legality of their decisions. Therefore, the Solicitor-General also has a leadership role in this matter.

\section{Conclusion}

For these reasons, there are several constraints and disadvantageous systemic issues facing involuntary participants of documentary reality television. These issues relate to privacy,

\footnotetext{
${ }^{337}$ Such as $S W v$ Television New Zealand, above n 53, where the film crew also obfuscated details about the filming.

338 Privacy Act 1993, s 13 (a) \& (m).
} 
but also to broader issues such as access to justice and the cost of civil litigation. That said, there are several solutions available that could resolve these issues relatively simply. 


\section{Conclusion}

This paper has considered the privacy implications of documentary reality television. By forming a framework for a breach of privacy, which is applicable to the courts and the BSA, it has demonstrated that there is a systemic issue with documentary reality television. But, general issues with access to justice and the BSA stand in the way of remedies for involuntary participants.

The BSA's own decisions support that the genre repeatedly breaches the privacy of involuntary participants. This is made worse by the fact that many of the BSA's decisions also disclose behaviour fundamentally undermining the Broadcasting Standards. These include behaviours such as concealing the purpose of filming and pressuring subjects to consent. The BSA was established with its own jurisdiction to provide media regulation, however, examples like these show it is not occurring. That Greenstone's own website says it will never broadcast personally identifiable information reveals an industry set up to convince people that what is happening is acceptable and lawful.

Finally, more concerning still is the Crown is intimately tied into the genre. Examples such as the broadcast of closed-circuit security cameras and information gained by searches show just how integrated public agencies have become with reality television. If a public authority accidentally sent the personal information of one person to another, it is broadly acknowledged to be a privacy breach. But what we see in documentary reality television is public authorities systematically contracting to release people's personal information to substantial mainstream television audiences in exchange for consideration.

The conclusions are not entirely bleak, as stated in chapter nine, there are several solutions. These solutions could lead to substantial improvements in the genre, without the need for case-by-case litigation of issues. The need for these solutions could reveal a lack of media regulation in New Zealand, or at least, that the media regulation that exists is not functioning as intended.

In reaching this conclusion, the paper has considered several contentious issues within privacy law. Matters such as the need for the highly offensive test, the status of law enforcement material and the role of plaintiff's conduct all require resolution.

The consideration of the highly offensive test reveals that it is conceptually unsound. The examples of courts' considerations reveal a lack of objective considerations, separated from facts relevant to the reasonable expectation of privacy test. The status of law enforcement material also reveals foundational issues needing to be resolved regarding basis and interaction of privacy and defamation. The inclusion of reputational harm as a factor in the establishment of a reasonable expectation of privacy reveals a risk of merging privacy and 
defamation actions and such uncertainty is bound to increase complexity in the pleadings and increases in the cost of litigation. For these reasons, further research is required.

If the Supreme Court confirms opt-out representative actions in Ross v Southern Response it will have a substantial impact on privacy claims. Such representative actions' key benefits align with the key difficulties with access to justice for privacy claimants. In particular, they allow claimants to share the cost of litigating an area replete with uncertainty. However, even this cost could be avoided if the Privacy Commissioner or the Solicitor-General considered the area and took action. The examples in this paper demonstrate that this action is justified. 


\section{Bibliography}

\section{A Cases}

\section{New Zealand}

ANZ Bank New Zealand Ltd v Financial Markets Authority [2018] NZHC 691.

Auckland Area Health Board v Television New Zealand Ltd [1992] 3 NZLR 406.

Andrews v Television New Zealand [2009] 1 NZLR 220 (HC).

Bradley v Wingnut Films Ltd [1993] 1 NZLR 415 (HC).

Brooker v Police [2007] NZSC 30.

Brown v Attorney-General [2006] DCR 630.

Brown v Dunsmuir [1994] 3 NZLR 485 (HC).

Brooks v New Zealand Guardian Trust Co Ltd [1994] 2 NZLR 134 (CA).

C v Holland [2012] NZHC 2155.

Clague v APN News and Media Ltd [2012] NZHC 2898.

Commerce Commission v Carter Holt Harvey Ltd [2008] 1 NZLR 387 (HC).

Director of Human Rights Proceedings v Dotcom [2019] NZHRRT 22.

Driver v Radio New Zealand Limited [2019] NZHC 3275.

Gaitau v R [2019] NZCA 32.

Hamed v R [2011] NZSC 101.

Henderson v Walker [2019] NZHC 2184.

Henderson v Slevin [2015] NZHC 366.

Hyndman v Walker [2019] NZHC 2188.

Hosking v Runting [2004] NZCA 34.

Houghton v Saunders (2008) 19 PRNZ 173 (HC).

$L v G$ [2002] DCR 234. 
$P v D$ [2000] 2 NZLR 591 (HC).

$R v$ Kahotea [2016] NZDC 24926.

$R v$ Williams [2007] NZCA 52.

Re McAllister [1990] NZAR 324.

Rogers v Television New Zealand [2007] 1 NZLR 156 (CA).

Rogers v TVNZ [2017] NZCA 82.

Rogers v TVNZ Ltd [2007] NZSC 9.

Ross v Southern Response [2019] NZCA 431.

Shaun Michael Moore v R [2017] NZCA 577.

Smith Kline and French Laboratories v Attorney General [1989] 1 NZLR 385.

Stepping Stones Nursery Ltd v Attorney-General [2002] 3 NZLR 414.

Southern Response Earthquake Services Limited v Ross [2019] NZSC 140.

Tucker v News Media Ownership Limited [1986] 2 NZLR 716 (HC).

Tucker v News Media Ownership [1986] 2 NZLR 716 (CA).

TV3 Network Services v Fahey [1999] 2 NZLR 129.

\section{Australia}

Australian Broadcasting Corporation v Lenah Game Meats [2001] HCA 63.

\section{United Kingdom}

$A v B$ [2002] EWCA Civ 337, [2002] 3 WLR 542.

Ali v Channel 5 (costs) [2018] EWHC 840 (Ch).

Ali v Channel 5 [2018] EWHC 298 (Ch).

Argyll v Argyll [1967] Ch 3012.

Ash v McKennit [2006] EQCA 1714 (Civ).

Ashton v Turner [1981] QB 137. 
Barrymore v Newsgroup Newspapers Ltd [1997] FSR 600.

Campbell v MGN Ltd [2002] EWCA Civ 1373, [2003] 2 WLR 80.

Campbell v MGN Ltd [2004] UKHL 22, [2004] AC 457.

Cliff Richard v BBC [2018] EWHC 1837 (Ch).

Douglas v Hello! Ltd [2005] EWCA Civ 595.

Entick v Carrington [1765] EWHC J98 (KB).

Gulati v MGN Ltd and others [2015] EWHC 1482 (Ch).

Gulativ MGN Ltd and others [2015] EWCA Civ 1291.

Holman v Johnson (1775) 1 Cowp 341 (KB).

Khuja (Appellant) v Times Newspapers Limited [2017] UKSC 49.

Marcel v Commissioner of Police of the Metropolis [1992] Ch 225.

McCartan Turkington Breen v Times Newspapers [2000] UKHL 57.

McKennitt v Ash [2006] EWCA Civ 1714, [2007] 3 WLR 194.

Murray v Big Pictures (UK) Ltd [2008] EWCA Civ 446, [2008] 3 WLR 1360.

Murray v Express Newspapers [2008] EWCA Civ 446 (Ch).

National Coal Board v England [1954] AC 403 (HL).

PJS v News Group Newspapers Ltd [2016] UKSC 26.

Prince Albert v Strange (1848) 2 De G \& SM 652, 698; 64 ER 293,

$R$ (Ingenious Media Holdings plc) v Revenue and Customs Commissioners [2016] UKSC 54.

$R$ (Simms) v Secretary for State for the Home Department [2000] 2 AC 115.

Re JR38 [2015] UKSC 42.

Terry v Persons Unknown [2010] EWHC 199 (QB).

Venables v News Group News Papers [2001] EWHC 32 (QC).

Weller v Associated Newspapers Ltd [2014] EWHC 1163 (QB). 
ZXC v Bloomberg [2009] EWC 970 (QB).

4 United States of America

Ayeni v CBS Inc 848 F Supp 364 (ED NY 1994).

Berger v Hanlon 129 F 3d 505 (9th Cir, 1997).

Daily Times Democrat v Flora Bell Graham 162 Supp 2d 474 (1964).

Dymond v National Broadcasting 559 F Supp 734 (D Del 1983).

Fletcher v Florida Publishing 319 Sup 2d 100 (Fla Dist Ct App, 1975).

Marich v MGM UA Telecommunications 113 Cal.App 4th 415 (Cal Ct Capp, 2003).

Miller v National Broadcasting Company 187 Cal App 3d 1463 (1986).

Shulman v. Group W Productions 55 P 2d 469 (Cal 1998).

United States v Sanusi 813 F Supp 149 (EDNY,1992).

Wilson v Layne 526 US 603 (1999).

\section{Europe}

Peck $v$ the United Kingdom [2003] EHRR 287.

Von Hannover (No 1) [2004] EMLR 379.

\section{B Broadcasting Standards Authority Decisions}

De Hart v TV3 Network Services Ltd BSA decision No 2000-108-113, 10 August 2000.

FS And Television New Zealand Ltd BSA Decision No 2012-036, 19 December 2012.

Gv Television New Zealand BSA Decision No 1999-229, 9 December 1999.

Johns v Television New Zealand BSA Decision No 1999-201, 11 November 1999.

MA v Television New Zealand BSA Decision No 2010-084, 22 February 2011.

MQ v Television New Zealand Ltd BSA Decision No 011-033, 13 September 2011.

PG v Television New Zealand Ltd BSA Decision No 2014-090, 16 June 2015.

PNv Television New Zealand Ltd BSA Decision No 2016-041, 15 September 2016. 
SWv Television New Zealand Ltd BSA Decision No 2015-030, 18 December 2015.

\section{Legislation}

\section{New Zealand}

Bill of Rights Act 1990.

Criminal Records (Clean Slate) Act 2004.

Crimes Act 1961.

Customs and Excise Act 2018.

High Court Rules 2016.

Law Reform Act 1936

Privacy Act 1993.

Policing Act 2008.

\section{United Kingdom}

The Human Rights Act 1998.

\section{International instruments}

United Nations Declaration of Human Rights 1948.

\section{E Books}

A Tomkins, Public Law (Oxford, Oxford University Press, 2003).

Annette Hill Reality TV: audiences and popular factual television (Routledge, London, 2005).

Annette Hill Reality TV: audiences and popular factual television (Routledge, London, 2005).

Broadcast Standards Authority Broadcasting Standards in New Zealand Codebook (Broadcasting Standards Authority, Wellington, 2016).

Christena Eng-Nipperts Islands of Privacy (Chicago University Press, Chicago, 2010).

Eric Barendt Freedom of Speech (2nd ed, Oxford University Press, New York, 2005). 
F Schauer Free Speech: A Philosophical Enquiry (Cambridge University Press, United Kingdom, 1982).

J Goudkamp, Tort Law Defences (Oxford, Hart Publishing, 2013).

James Duane, You have the right to remain innocent (Little A, Seattle, 2016).

John Burrows and Ursula Cheer Media Law in New Zealand (7th ed, Oxford University Press, Melbourne, 2015).

J S Mill On Liberty (Cambridge University Press, Cambridge, 2012).

Kathryn Tate "California's Anti-SLAPP legislation: a summary and a commentary on its operation and scope” (2000) 4 Loyola Law Review 1.

Maggie Wykes and Kirsty Welsh Violence, Gender and Justice (Sage Publications, California, 2009).

Mark Warby, Nicole Moreham Tugendhat and Christie Law of Privacy and the Media (3nd ed, Oxford University Press, 2016).

Mary Beth Oliver "Portrayals of crime, race, and aggression in "reality based" police shows: A content analysis" (1994) 38(2) Journal of Broadcasting \& Electronic Media 179.

Michael McKenna Real People and the Rise of Reality Television (Rowman \& Littlefield Publishers, Maryland, 2015).

Paul Kooistra, John Mahoney and Saundra Westervelt (1998) "The World of Crime According to 'Cops'" in G Cavender and M Fishman (eds) Entertaining Crime: Television Reality Programs (Aldine De Gruyter, New York, 1998) 141.

Paul Mason Criminal visions media representation of crime and justice (Cullompton, Devon, 2003).

Stephen Penk and Rosemary Tobin (eds) Privacy Law in New Zealand (2nd ed, Brookers, Wellington, 2010)

Bloustein Individual and group privacy (2nd ed, Routledge, New Brunswick, 2003).

\section{F Journals}

Charles Fried, "Privacy" (1968) 77 Yale LJ 475 at 484.

Daniel Lassiter and others "Evidence of the camera perspective bias in authentic videotaped interrogations: Implications for emerging reform in the criminal justice system" (2011) 14(1) Legal and Criminology Psychology 157.

Dean William L Prosser "Privacy" (1960) 48 Calif L Rev 383, 409. 
Edward J Bloustein "Privacy as an aspect of human dignity: an answer to Dean Prosser" in Ferdinand D Schoeman (ed) Philosophical Dimensions of Privacy: An Anthology (Cambridge University Press, United Kingdom, 1984) 156.

Elizabeth Monk-Turner and others "Are reality TV crime shows continuing to perpetuate crime myths" (2007) Internet Journal of Criminology.

Eric Barendt Freedom of Speech (2nd ed, Oxford University Press, New York, 2005).

Eric Barendt, "Privacy as a Constitutional Right and Value" at (10) in Peter Birks (ed) Privacy and Loyalty (Clarendon Press, Oxford, 1997).

June Deery "Reality TV as Advertainment” (2004) 2 Popular Communication 1.

Kathryn Tate "California's Anti-SLAPP legislation: a summary and a commentary on its operation and scope” (2000) 4 Loyola Law Review 1.

Kirsty Hughes "A Behavioural Understanding of Privacy and Its Implications for Privacy Law” (2012) 75(5) Modern Law Review 806.

Henry Rossbacher, Tracy Young and Nanci Nishimura "An Invasion of Privacy: The Media's Involvement in Law Enforcement Activities” (1991) 19 Loy LA Ent L Rev 313.

James Rachels "Why Privacy is Important" (1975) 4(4) Philosophy and Public Affairs 323.

Jennifer Moore "Traumatised Bodies: Towards Corporeality in New Zealand's Privacy Tort Law Involving Accident Survivors" (2011) 24 NZULR 387.

Nicole Moreham "Hosking v Runting and the protection of privacy in public places" [2006] NZLJ 265.

Nicole Moreham "Privacy in Public Places" (2006) 65 CL J 606.

N A Moreham "Unpacking the reasonable expectation of privacy test" (2018) 134 LQR 651.

N A Moreham “Abandoning the Highly Offensive Test” (2018) 4 CJCCL 1.

Nicole Moreham "The protection of Privacy in English Common Law: a doctrinal and theoretical analysis" (2005) 121 LQR 628 at 636.

Nicole Moreham and Yvette Tinsley "Grief Journalism, Physical Intrusion, and Loss: The Pike River Coal Mine Disaster" in Andrew T Kenyon (ed) Comparative Defamation and Privacy Law (Cambridge University Press, 2016) 115.

Megan Richardson "Privacy and Precedent: The Court of Appeal's Decision in Hosking v Runting” (2004) 11 NZBLQ 82. 
Petra Butler "The Case for a Right to Privacy in the New Zealand Bill of Rights Act" (2013) 11(1) New Zealand Journal of Public and International Law 213.

Richard Kilborn "How real can it get" (1994) European Journal of Communication, 9 (4) 421.

Robert Turner "New Sheriffs" in England and Wales - An Account of the New High Court Enforcement Regime and the Creation of the High Court Enforcement Officers" (2012) 23(1) European Business Law Review 121.

Ruth Gavinson "Privacy and the Limits of Law (1980) 89 Yale Law Journal 421.

Stanley Benn 'Privacy, Freedom and respect for persons' in Pennock and Chapman (eds) Privacy (NOMOS vol XIII, Atherton Press, New York, 1971) 1.

Sara Landström, Emma Roos Af Hjelmsäter and Pär Anders Granhag "The camera perspective bias: a case study" (2008) 4(3) Journal of Investigative Psychology and Offender Profiling 199.

Tracey Jensen "Welfare Commonsense, Poverty Porn and Doxosophy"(2014) 19(3) Sociological Research Online 1.

Wesley Newcomb Hohfeld "Fundamental Legal Conceptions as Applied in Judicial Reasoning” (1917) 26(8) Yale Law Journal 710.

William Fussey "Determining Reasonable Expectations of Privacy in the Intrusion into Seclusion Tort” (2016) 22 Canterbury Law Review 269.

\section{$G$ Reports}

Broadcasting Standards Authority "The Real Deal” (1 September 2011).

Lord Justice Leveson An inquiry into the culture, practice and ethics of the press (Leverson Inquiry, November 2012).

Nielson "Media Trends 2016" (June 2016) < https://www.nielsen.com>.

\section{H Newspaper articles}

Chris Keall "Seven Sharp in ratings tailspin/ On human bondage" National Business Review (08 Feb 2013) <www.nbr.co.nz>.

David Lohr "Baltimore Cop Accused Of Planting Drugs In Body Cam Video Indicted" (25 Janruary 2018) Huffpost <Huffpost.com>.

Guy Davies “Watching the Detectives” Independent (London, 7 September 1999). 
Melanie Reid "New Zealand's own taken generation” (11 June 2019) Newsroom.co.nz <https://www.newsroom.co.nz >.

NZHerald "Beach feud flares at Piha" NZHerald (Online edition, 18 March 2012).

Max Kutner,"Will 'Cops' Survive the Turned Tide on Police Videos?" Newsweek 17 July 2015 <Newsweek.com>.

Stuff "Police Apologise after offer threatens to ticket filming teenage" 20 January 2019 $<$ https://www.stuff.co.nz >.

Stuff "Man dies after leap from brothel window" (31 January 2009) <www.stuff.co.nz>.

Stuff "The reality of reality - the dumbing down continues" (12 November 2014) <www.stuff.co.nz>.

Stuff "Baffling ratings at 7pm" (29 January 2013) <www.stuff.co.nz>.

Stuff "Death after TV brothel raid" (31 January 2009) <www.stuff.co.nz>.

Stuff "Police Apologise after offer threatens to ticket filming teenage" 20 January 2019 $<$ https://www.stuff.co.nz >.

Tom Shales "Keep Quiet, “America"” Washington Post (America, 1 August 1980) available online at <https://www.washingtonpost.com>.

Tony Schwartz "George Schlatter Finds The Fun In TV” New York Times (6 May 6,1982).

Screenonline "Police (1982) < http://www.screenonline.org.uk/tv/id/464502/index.html>.

UPI “Thatcher joins in rape controversy” UPI (London, 19 January 1982).

Willie Versteeg "Everyone Should Be Watching the Reality Show Cops Right Now. Seriously." Slate 8 March $2016<$ www.slate.com>.

\section{$H$ Documents obtained under the Official Information Act}

Approval dated 15 August 1991 to Anna Cahill of Wingnut Films (Obtained under the Local Government Official Information and Meetings Act 1987 to Wellington City Council).

Border Patrol Series 7 Production Agreement (Obtained under Official Information Act 1982 request to the Ministry of Primary Industries).

Legal advice to David Rowe, Park Manager, from Ann Callaghan, City Solicior, titled "Bolton Street Cemetery - Filming" dated 19 May 1992 (Obtained under the Local Government Official Information and Meetings Act 1987 request to Wellington City Council). 
Motorway Series 18 Production Agreement (Obtained under Official Information Act 1982 request to the Police).

Police Ten 7 series 27 Production Agreement (Obtained under Official Information Act 1982 request to the Police).

\section{Internet Material}

Greenstone TV "Will I be on TV?" < http://www.greenstonetv.com/will-i-be-on-tv/>.

Bondi Rescue "Bondi Lifeguard Whippet Rescues A Topless Woman" (10 July 2011) <https://www.youtube.com/watch?v=yPIIJfqsGNc〉.

Breakfast "Paul Henry Interviews the Blow on the Pie Guy on Breakfast" (23 October 2009), <https://www.youtube.com/watch?v=132ADJOr3RY>.

"Television \& Steaming Video on Demand" Performance Media $<$ http://www.performancemedia.co.nz/television.html>.

\section{$J$ Television shows}

"Bondi Rescue" Cordell Jigsaw Productions.

“Popstars" Screentime.

"Fire fighters" Greenstone TV Limited.

"Married at First Sight" Warner Brothers.

“Motorway Patrol” Greenstone TV Limited.

"Pioneer House" Touchdown Productions.

“Police Ten 7" Screentime.

"Police" British Broadcasting Corporation.

“RBT” Screentime.

“Road Cops" Starfish Pictures Limited.

"The Bridge" IFC Films.

“The Business of Being Born” Barranca Productions.

"Time of Death" Showtime. 